NASA

Technical Memorandum 88796

AIAA-86-1542
USAAVSCOM

Technical Report 86-C-23

NASA-TM-88796

19860022115

\title{
An Overview of the Small Engine Component Technology (SECT) Studies
}

M.R. Vanco, W.T. Wintucky, and R.W. Niedzwiecki Lewis Research Center Cleveland, Ohio

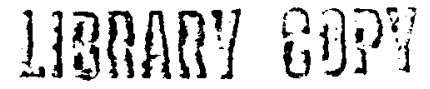

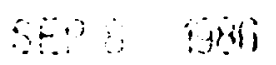

LANGIEY FESEFITCH CENTER LIERARY, NASI

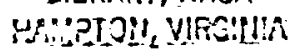

Prepared for the

22nd Joint Propulsion Conference cosponsored by the AIAA, ASME, SAE, and ASEE Huntsville, Alabama, June 16-18, 1986

\section{N/Sก}



DISFLAY $21 / 6 / 1$

86N31587*\# ISSUE 23 FAGE 3558 CATEGOFY 7 FFTH: NASA-TM-89796

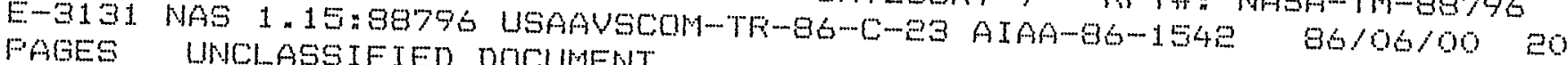

UTTL: An averview of the Small Engine Component Technalagy (SECT) studies

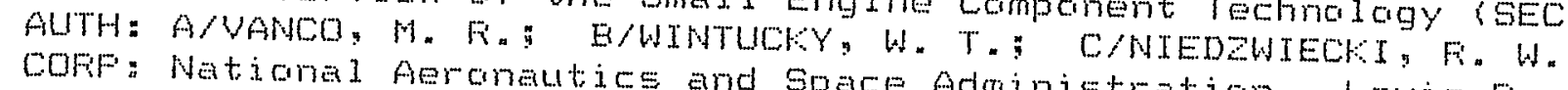

Cleveland, onic.

SAF: AVail: NTIS HC AOE/NF AOL

CIOn UNTTED STATES Fresented at the eand Joint Fropulsian Conference,

Huntsville, Ala. 16-18 Jun. 1986 " cosponsored by AIAA, ASME, SAE, and
ASEE

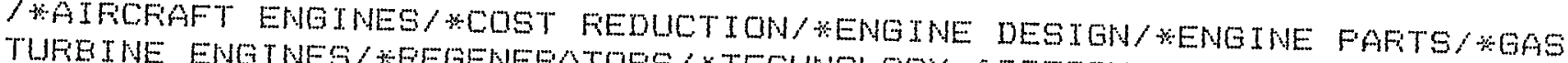

TUFBOFFOF ENGINES

MTNS: I CEFAMTCS/ COMEFCIAL ATFCFAFT/ CFUISE MISSILES/ FUEL CONSUMFTION/ OFERATING COSTS/ FASSENGEF ATRCRAFT/ TILT ROTOF AIFCFAFT

ABA: Authar 


$$
-\cdots-\ldots \ldots
$$




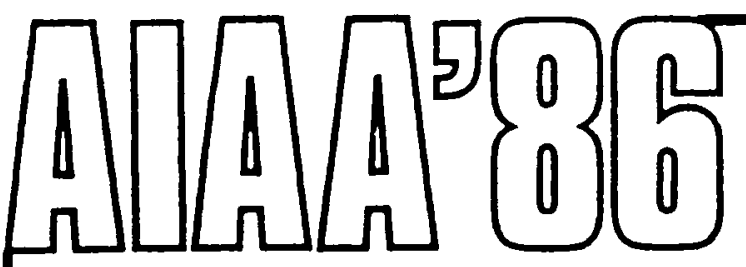

AIAA-86-1542

An Overview of the Small Engine Component Technology (SECT) Studies

M.R. Vanco, W.T. Wintucky, and

R.W. Niedzwiecki, NASA Lewis Research

Center, Cleveland, $\mathrm{OH}$

\section{AIAA/ASME/SAE/ASEE 22nd Joint Propulsion Conference June 16-18, 1986/Huntsville, Alabama}


AN OVERVIEW OF THE SMALL ENGINE

COMPONENT TECHNOLOGY (SECT) STUDIES

M.R. Vanco, W.T. Wintucky, and R.W. Niedwiecki

National Aeronautics and Space Administration

Lewis Research Center

Cleveland, Ohio 44135

\section{Abstract}

The objectives of the joint NASA/Army SECT Studies were to identify high payoff technologies for year 2000 small gas turbine engine applications and to provide a technology plan for guiding future research and technology efforts applicable to rotorcraft, commuter and general aviation aircraft and cruise missiles. Competitive contracts were awarded to Allison, AVCO Lycoming, Garrett, Teledyne CAE and Williams International. This paper presents an overview of the contractors study efforts for the commuter, rotorcraft, cruise missile, and APU applications with engines in the 250 to 1,000 horsepower size range. Reference aircraft, missions and engines were selected. Advanced engine configurations and cycles with projected year 2000 component technologies were evaluated and compared with a reference engine selected by the contractor. For typical commuter and rotorcraft applications, fuel savings of 22 percent to 42 percent can be attained. For $\$ 1 /$ gallon and $\$ 2 /$ gallon fuel, reductions in direct operating cost range from 6 percent to 16 percent and from 11 percent to 17 percent respectively. For subsonic strategic cruise missile applications, fuel savings of 38 percent to 54 percent can be achieved which allows 35 percent to 60 percent increase in mission range and life cycle cost reductions of 40 percent to 56 percent. High payoff technologies have been identified for all applications.

\section{Introduction}

Small gas turbine engine performance in the 250 to 1,000 horsepower size range is significantly lower than that of large engines. The major reasons are that: 1 . component efficiencies for small engines are from 8 to 10 percentage points lower than those of large engines; and 2. small engine cycle pressure ratios and turbine inlet temperatures are considerably lower than large engines. Analytical design techniques and manufacturing techniques of large engines are not directly transferable to small engines. Current research on very small (100 horsepower) gas turbine automotive engines and general studies of the application of this research to aircraft engines indicate that ceramics and regenerative cycles also have the potential for significant improvement in fuel savings for aircraft gas turbine engines. With the incorporation of ceramics, regenerative cycles, and a significant improvement in component performance, the year 2000 technology small gas turbine engines could achieve fuel savings on the order of 50 percent.
To achieve these fuel savings, an aggressive small engine component technology program is required. The overall program approach is to evoive, evaluate and verify the needed advanced technology for gas turbine engines of 250 to 1000 norsepower suitable for use in rotorcraft, general aviation and commuter aircraft, and cruise missiles. Most of the technology is common to all of the applications. The program consists of: 1 . system studies and technology assessment; 2. discipline research and technology; and 3. component research and technology. The first step in the program was a study effort to identify high payoff technologies for year 2000 small gas turbine engine applications, and provide a technology plan for guiding future research and technology efforts. To complete this first step, competitive contracts were awarded to Allison Gas Turbine Division - General Motors Corporation, AVCO Lycoming Textron, Garrett Turbine Engine Co., Teledyne CAE and williams International. These contracts were joint programs sponsored by NASA Lewis Research Center and the U.S. Army Aviation Research and Technology Activity - Propulsion Directorate. This paper presents an overview of the contractor study efforts for the commuter, rotorcraft, cruise missile and APU applications.

\section{Program Scope}

Each contractor study effort consisted of: selection of mission evaluation procedures and assumptions; evaluation of engine configurations and cycles, engine/aircraft mission analysis to determine figures-of-merit to rank technologies; and preparation of a technology plan to guide research and technology verification, component and systems research and technology programs.

Selection of Evaluation Procedures and Assumptions

Each contractor selected one or more of the following year 2000 small gas turbine engine applications: high performance, high pressure ratio, high power/weight rotorcraft engine; low pressure ratio, low SFC regenerative commuter or rotorcraft engine; nigh power density, low SFC APU; or low cost, high performance cruise missile engine.

Reference aircraft, mission type, range, Mach number capability, and passenger load factors were selected. Aircraft and mission were based on projections for year 2000. Aircraft weights were reduced by use of composites. Company marketing projections were used for the mission profile, and number of passengers and/or payload. 
Current technology engines were used as base for the reference engine. Engines were scaled as required to meet the mission requirements. Reference engine performance, weight and cost were provided by the contractor as a basis for comparison.

For the commuter, rotorcraft and APU applications, fuel prices of $\$ 1 /$ gal and $\$ 2 /$ gal were used. This price range should bracket the projected fuel cost increase anticipated for the year 2000 and will show the effects of doubling the fuel cost. For cruise missile application, JP-10 fuel was selected. Direct operating cost $(D O C)$ was selected as the figure-of-merit for commuter, rotorcraft and APU applications whereas, life cycle cost (LCC) was selected for cruise missile. 1985 year dollars were used for all cost calculations. All appropriate proposed and existing noise and emission regulations were examined or investigated for application to the selected configurations.

Trade factors such as $\triangle D O C$ versus specific fuel consumption (SFC), engine weight, and engine cost were used to evaluate engine configurations and cycles.

\section{Engine Configuration and Cycle Evalution}

Advanced cycles investigated for each application were: 1. advanced simple cycle with pressure ratios to $30: 1 ; 2$. nonconcentric cycles with pressure ratios from $30: 1$ to $45: 1$; and recuperator/regenerator cycles with pressure ratios to 14:1. For these advanced cycles, component efficiencies - 3 to 5 points above current technology levels, and materials ceramic/ceramic composites, single crystal, powder metallurgy PM materials for disks, were assumed. Turbine rotor inlet temperatures (TRIT) in the range of $2200^{\circ} \mathrm{F}$ to $3500^{\circ} \mathrm{F}$ were investigated along with cooled and uncooled turbines. Trade factors mentioned above were used to select the best engine configuration(s)/cycle(s).

Systems Performance Evaluation - Engine/Aircraft Mission Analysis

Mission analyses were conducted to determine effects of advanced technology engines on system performance. Advanced technology engines and reference engines were flown in aircraft over the same mission. The advanced technology engine aircraft sizes were adjusted for engine size effects and fuel consumption. Aircraft technology was the same for both aircraft. Fuel burned, cost, and an appropriate operational cost parameter (DOC or LCC) were determined for each advanced technology engine and reference engine.

\section{Identification of Technologies}

Based on the mission analysis, the potential benefits for each advanced technology in the engines were determined and the technologies were ranked in order of decreasing benefit. Technology plans were prepared for guiding future government research and technology efforts.

\section{Contractor Results}

Summary of the results for Allison, AVCO Lycoming, Garrett, Teledyne CAE and Williams International individual SECT Studies is presented in the following sections.

\section{Allison}

Allison selected a commercial rotorcraft application. Details of the Allison SECT Study, Contract NAS3-24542, are presented in Reference 1. The eight passenger tilt rotor executivel commercial aircraft shown in Figure 1 was selected as the reference aircraft. The mission for the twin turboshaft powered tilt rotor aircraft is 350 nautical miles with cruise speed of 250 knots at an altitude of 20,000 feet. Figure-of-merit is direct operating cost. The reference engine, which is based on a current technology engine has TRIT of $2200^{\circ} \mathrm{F}$, pressure ratio of $14: 1$, and 1,000 shaft horsepower (hp) at sea level static (SLS) take-off.

The following cycles were investigated: 1 . advanced simple cycle with pressure ratios to $25: 1$; 2 . nonconcentric simple cycles with pressure ratios to $40: 1 ; 3$. heat recovery cycles with pressure ratios to $14: 1$; and 4 . a cycle using a wave pressure exchanger or a wave rotor in the high pressure system with pressure ratios to $45: 1$. These cycles were investigated with TRIT in the range of $2200^{\circ} \mathrm{F}$ to $2800^{\circ} \mathrm{F}$ and projected year 2000 component efficiencies. Uncooled and cooled turbines were examined. Because of the manufacturing problems associated with a small size cooled turbine and the significant performance penalty, cooled turbines were eliminated. Turbine rotor inlet temperature of $2800^{\circ} \mathrm{F}$ was selected based on the not spot temperature capability of ceramic composite material and projected year 2000 combustor pattern factor less than .2. Regenerator and recuperator effectiveness in the range of .6 to .8 and pressure drops of 6 percent to 14 percent were considered. The optimum cycle parameters for each advanced cycle considered are:

\begin{tabular}{|c|c|c|c|c|c|}
\hline & Concentric & $\begin{array}{c}\text { Non- } \\
\text { Concentric }\end{array}$ & Recup. & Regen. & $\begin{array}{l}\text { Wave } \\
\text { Rotor }\end{array}$ \\
\hline Pressure Ratio & 25 & 30 & 14 & 10 & 38 \\
\hline TRIT, ${ }^{\circ} \mathrm{F}$ & 2800 & 2800 & 2800 & 2800 & 2800 \\
\hline $\begin{array}{l}\text { Effectiveness } \\
\qquad P / P\end{array}$ & & & .6 &.$i^{7}$ & \\
\hline LP Compressor & Axial & Axi-Centrif. & - & - & $\begin{array}{c}\text { Axiall } \\
\text { Centrif. }\end{array}$ \\
\hline HP Compressor & Centrif. & Centrif. & $\begin{array}{c}\text { Axiall } \\
\text { Centrif. }\end{array}$ & $\begin{array}{c}\text { Axiall } \\
\text { Centrif. }\end{array}$ & $\begin{array}{l}\text { Wave } \\
\text { Rotor }\end{array}$ \\
\hline HP Turbine & Radial & Radial & Axial & Axial & $\begin{array}{l}\text { Wave } \\
\text { Rotor }\end{array}$ \\
\hline LP Turbine & Axial & Radia: & - & - & Axial \\
\hline Power Turbine & Axial & Axial & Axial & Axial & Axial \\
\hline
\end{tabular}

Selection of each advanced cycle was based on relative $D O C$ from the trade factor analysis which included $\triangle D O C$ as function of SFC, engine weight, engine cost/shaft $h p$, engine length, and engine height. 
A preliminary analysis of the five configurations was conducted. The wave rotor cycle was eliminated from further consideration because new codes were becoming available which would allow a more complete analysis and evaluation. The concentric simple cycle was eliminated because the preliminary design analysis indicated that the bore stress in the ceramic HP turbine was prohibitive. Therefore, the three cycles selected for the mission analysis were nonconcentric, recuperative and regenerative.

The three advanced technology engines and reference engine were installed in tilt rotor aircraft and flown over the reference mission. Reductions in fuel burned for the advanced engines are 30.5 percent for regenerative, 30.7 percent for recuperative and 30.1 percent for nonconcentric compared to the reference engine. The resulting reductions in $D O C$ for $\$ 1 / g a l$ fuel cost are 10.9 percent for regenerative, 12.8 percent for recuperative, and 16.5 percent for nonconcentric. The difference in DOC reductions for the three configurations is due to the complexity, weight, cost, and maintenance cost of the recuperator and regenerator. As can be seen from Figure 2, there is only about one point difference in DOC between $\$ 1 / \mathrm{gal}$ and $\$ 2 / g a l$ fuel cost. This is due to the small fuel weight fraction for this aircraft and mission. Based on DOC considerations, the nonconcentric configuration was selected.

The general arrangement of the nonconcentric engine is shown in Figure 3 . This configuration has the following; TRIT of $2800^{\circ} \mathrm{F}$, pressure ratio of 30 , axial/centrifugal low pressure (LP) compressor, centrifugal high pressure (HP) compressor, radial HP turbine, radial LP turbine, and axial power turbine. Required advanced technologies are ceramic/ceramic composites for the combustor and turbine, aerodynamics - highly efficient components and threedimensional codes, and bearings for reliability and durability. For $\$ 1 /$ gal fuel cost, advanced materials - ceramics/ceramic composites provide 58 percent of DOC reduction and advanced aerodynamics provide 40 percent of the DOC reduction. The advanced aerodynamic technologies by priority are turbine, compressor and combustor. Bearing DOC benefit was not calculated because the high speed bearings are needed to achieve gains from materials and aerodynamics.

\section{Avco Lycoming}

Lycoming selected the commuter application. Details of the AVCO Lycoming SECT Study, Contract NAS3-24545, are presented in Reference 2. The nineteen passenger commuter aircraft shown in Figure 4 was selected as the reference aircraft. The sizing mission for the twin turboprop aircraft is 600 nautical miles with 19 passengers. The economic mission is 100 nautical mile segments with 65 percent payload. Figure-of-merit is direct operating cost. The reference engine which is based on a current technology engine has TRIT of $2240^{\circ} \mathrm{F}$, pressure ratio of $13: 1$ and 960 shaft hp at SLS take-off.

A recuperated cycle was selected with the following parametric variations at the cruise condition; TRIT from $2100^{\circ} \mathrm{F}$ to $2700^{\circ} \mathrm{F}$, pressure ratio of 5 to 10, recuperator effectiveness of .7 to .9 , and recuperator pressure loss of 4 percent to .08 percent. Cooled and uncooled turbines, advanced materials - single crystal superalloys and ceramic/ceramic composites, and single pass and two pass recuperator configurations were investigated. Eight individual technologies were incorporated. Cycles were optimized to determine the recuperator effectiveness which provided minimum SFC for each technology level. Fuel burn reduction for the individual technologies is shown in Figure 5 for TRIT of $2500^{\circ} \mathrm{F}$ at cruise. $\Delta$ fuel burned is based on the established trade factors. As can be seen from Figure 5 , a 42 percent reduction in fuel burned is obtained at recuperator effectiveness of $\sim 83$ percent for an advanced technology engine. TRIT of $2500^{\circ} \mathrm{F}$ at cruise which translates to $2640^{\circ} \mathrm{F}$ at take-off was selected based on ceramic/ceramic composite not spot temperatures at take-off and year 2000 combustor pattern factor less than .2. Aircraft parameters such as DOC, take-off gross weight (TOGW), etc., are functions of engine SFC, propulsion system weight and frontal area, engine cost, and maintenance cost. The $\triangle D O C$ for the individual technologies is shown in Figure 6 for $\$ 2 / g a l$ fuel cost. As can be seen from Figure $6, \triangle D O C$ is flat between recuperator effectiveness from .7 to .82 . Based on fuel burn considerations and engine/aircraft integration technology program, recuperator effectiveness of .8 was selected.

A preliminary design analysis of the recuperated engine configuration shown in Figure 7 indicated that this configuration was feasible for year 2000. The recuperator diameter was selected to minimize the effect of frontal area on aircraft drag. The engine/aircraft integration must be included in the technology program. As can be seen from Figure 7, this results in a recuperator with a length approximately equal to the length of the engine and gearbox. The recuperator weight is approximately equal to the weight of the engine plus gearbox and accessories. This configuration has the following characteristics: TRIT = $2640^{\circ} \mathrm{F}$ at take-off; pressure ratio $=8.9$ at take-off; recuperator effectiveness $=.8$; axial/centrifugal compressor; single stage uncooled high pressure turbine; and two-stage uncooled power turbine.

Mission analysis results for the economic mission indicate that the recuperated engine has 38.3 percent reduction in fuel burned and 17 percent reduction in $D O C$ for fuel cost of $\$ 21$ gal (12.5 percent for $\$ 1 / \mathrm{gal}$ ) compared to the reference engine. Required advanced technologies are ceramics for the combustor and turbine, aerodynamics, and ceramic recuperator. For \$21 gal fuel cost (\$1/gal), advanced materials ceramic/ceramic composites provide 55 percent (65 percent) of the DOC reduction, advanced aerodynamics provide 25 percent ( 29 percent) of the DOC reduction, and ceramic recuperator provides 20 percent ( 6 percent) of DOC reduction. Advanced derodynamic technologies by priority are compressor and turbine. Combustor technology is required to obtain pattern factors less than .2. 


\section{Garrett}

Garrett selected all four applications. Details of the Garrett SECT Study, Contract NAS3-24544, are presented in Reference 3. Only the results for the rotorcraft application, commuter application, and APU application are summarized here.

Rotorcraft. The utility helicopter shown in Figure 8 was selected for a military/civil mission. The mission which is shown in Figure 9 consists of five segments with four hover periods and total mission length of 130.4 nautical miles. Figure-of-merit is direct operating cost. The reference engine which is based on a current technology engine has TRIT of $2100^{\circ} \mathrm{F}$, a pressure ratio of 13.5 , and $1,000 \mathrm{hp}$ at SLS take-off.

Advanced simple cycles with pressure ratios to 26:1 and recuperated cycles with pressure ratios to $12: 1$ were investigated. Recuperator effectiveness of .6 to .8 and pressure loss $\Delta P / P$ of .06 to .10 were evaluated. These cycles were evaluated with TRIT in the range of $2200^{\circ} \mathrm{F}$ to $2800^{\circ} \mathrm{F}$ with uncooled and cooled turbines. Based on the trade factor analysis which included $D O C$ as a function of specific fuel consumption, engine cost, maintenance cost, engine weight, etc., an advanced simple cycle and a recuperated cycle with the following parameters were selected:

\begin{tabular}{lcc} 
& Advanced Simple Cycle & Recuperated Cycle \\
\cline { 2 - 3 } IRIT & $2600^{\circ} \mathrm{F}$ & $2600^{\circ} \mathrm{F}$ \\
Pressure Ratio & $22: 1$ & $10: 1$ \\
Compressor & 2-Stage Centrifugal & $\begin{array}{l}1-S t a g e \text { Centrifugal } \\
\text { HP Turbine }\end{array}$ \\
LP Turbine & Axial, Uncooled & Axial, Uncooled \\
Recuperator Effectiveness & & Axial, Variable Geom- \\
etry, Uncooled
\end{tabular}

Selection of TRIT of $2600^{\circ} \mathrm{F}$ is based on hot spot temperature capability of the ceramic/ ceramic composite material and year 2000 combustor pattern factor less than .2 .

Helicopter mission analysis results are shown in Figure 10. Reduction in fuel burned is 21.9 percent for simple cycle and 41.6 percent for recuperated cycle compared to the reference engine. At $\$ 1 /$ gal fuel cost, both cycles have the same reductions in DOC, approximately 7 percent. Recuperator weight and cost offset the additional reduction in fuel burned of the recuperated cycle. But at $\$ 2 / \mathrm{gal}$, the recuperated cycle has 11.4 percent reduction in $D O C$, 2.7 points more than the simple cycle. The increased fuel cost more than offsets the recuperator weight and cost. The required advanced technologies are materials - ceramic/ceramic composites, and $\mathrm{Ni}_{3} \mathrm{Al}$ disk, aerodynamics, ceramic recuperator and system technologies (metal matrix shafts, bearings and seals). For $\$ 1 / \mathrm{gal}$ fuel, the advanced materials provide 65 percent of DOC reduction (45 percent ceramics and 20 percent advanced metallic disk), and advanced aerodynamics provide 30 percent of DOC reduction. For $\$ 2 / \mathrm{gal}$ fuel, the breakdown is 43 percent for advanced materials, 34 percent for advanced aerodynamics, and 22 percent for ceramic recuperator. System technologies bearings, seals, and metal matrix shafts are necessary to achieve gains from materials and aerodynamics especially for the simple cycle. Advanced aerodynamic technologies by priority are turbine, compressor, and combustor.

Commuter. The nineteen passenger twin turboprop aircraft shown in Figure 11 was selected as the reference aircraft. The reference mission has 400 nautical mile range with three stops and the mission profile is shown in Figure 12. The reference engine uses the same technology as the rotorcraft reference engine.

Cycle analysis for the commuter application included the advanced simple cycle, recuperated cycle, and regenerated cycle. Cycle parameters evaluated for the regenerated cycle were; TRIT from $2400^{\circ} \mathrm{F}$ to $2800^{\circ} \mathrm{F}$, pressure ratio from $4: 1$ to $10: 1$, and regenerator effectiveness from .8 to .95 (pressure drop of 5 percent and leakage of 7 percent were held constant). Aavanced simple cycle and recuperated cycle analyses were the same as those presented for rotorcraft. Cycle parameters which yielded the lowest relative $D O C$ for the recuperated, regenerated, and simple cycle are presented in Figure 13. As can be seen from the figure for $\$ 2 / \mathrm{gal}$ fuel cost, the recuperated cycle has the lowest DOC. At $\$ 1 / \mathrm{gal}$, the recuperated cycle and advanced simple cycle are approximately the same. Even though the regenerated cycle has the SFC advantage, the increased weight, size, and cost offset this advantage. Therefore, the recuperated cycle with the following parameters was selected: TRIT $=2600^{\circ} \mathrm{F}$; pressure ratio $=$ 10; single stage centrifugal compressor; axial, uncooled high pressure turbine; multi-stage axial uncooled low pressure turbine; recuperator effectiveness $=.8$; and recuperator pressure loss $\triangle P / P=.08$.

Mission analysis results for the reference aircraft and mission indicate that the recuperated cycle nas a reduction in fuel burned of 35 percent compared to the reference engine. Resulting reductions in $D O C$ are 5.7 percent for $\$ 1 / \mathrm{gal}$ fuel cost and 11.1 percent for $\$ 2 /$ gal fuel cost. Required advanced technologies are materials, aerodynamics, ceramic recuperator and system technologies. Technology rankings are the same as those for the rotorcraft at $\$ 2 / \mathrm{gal}$ fuel cost.

APU. Reference aircraft is 150 passenger short-naul commercial transport. Reference mission is the APU duty cycle for 150 passenger year 2000 aircraft. This mission assumes the APU operators one hour/flight hour. The APU engine provides power for main engine starting, cabin air conditioning, electrical and hydraulic power, and emergency electrical and hydraulic power in flight. Figure-of-merit is direct operating cost. Reference engine has turbine inlet temperature (TIT) of $1900^{\circ} \mathrm{F}$, pressure ratio of 5.4, and sea level maximum rating of $360 \mathrm{hp}$.

Advanced simple cycles and regenerated cycles were investigated for the following cycle parameters: TIT from $1900^{\circ} \mathrm{F}$ to $2500^{\circ} \mathrm{F}$; cycle 
pressure ratio from $5: 1$ to $10: 1$; and regenerator parameters based on the NASA/DOE AGT 101. Several turbine and compressor configurations were examined. Based on trade factor DOC results, the following cycles were selected:

\begin{tabular}{|c|c|c|}
\hline & Advanced Simple Cycle & Regenerated Cycle \\
\hline $\begin{array}{l}\text { TIT, "F } \\
\text { Cycie Pressure Ratio } \\
\text { Regenerator Effectiveness } \\
\text { Compressor } \\
\text { Turbine }\end{array}$ & $\begin{array}{r}2500 \\
8 \\
\text { Radial } \\
\text { Radial uncooled }\end{array}$ & $\begin{array}{c}2500 \\
5.2 \\
.94 \text { (3 percent leakage } \\
\text { Radial } \\
\text { Radial uncooled }\end{array}$ \\
\hline
\end{tabular}

Turbine inlet temperature was selected based on material limitations.

Mission analysis results for both cycles are snown in Figure 14. Reduction in fuel burned is 43.2 percent for simple cycle and 70.8 percent for the regenerated cycle. At $\$ 1 / \mathrm{gal}$ fuel cost, the resulting reduction in $\mathrm{DOC}$ is 39 percent for the regenerated cycle, and 36.7 percent for the advanced simple cycle. At $\$ 2 / \mathrm{gal}$ fuel cost, the reductions in DOC are 47 percent for the regenerated cycle and 38.3 percent for advanced simple cycle. Ceramics and advanced aerodynamics are the required technologies.

\section{Teledyne CAE}

Teledyne CAE selected the cruise missile application. Details of the Teledyne SECT Study, contract NAS3-24541, are presented in Reference 4. A subsonic strategic mission was selected and the mission profile is shown in Figure 15. The reference missile configuration is shown in Figure 16. Figure-of-merit is life cycle cost. The reference engine has TRIT of $2060^{\circ} \mathrm{F}$ and pressure ratio of 12 at sea level.

The following cycles were investigated: two-spool turbofan with overall pressure ratios (OPR) to 30:1; three-spool turbofan with overa11 pressure ratios in the range of $30: 1$ to 45:1; two-spool propfan with overall pressure ratios to 30:1; and three-spool propfan with overall pressure ratios in the range of $30: 1$ to $45: 1$. These cycles were evaluated with TRIT in the range of $2100^{\circ} \mathrm{F}$ to $3500^{\circ} \mathrm{F}$ for uncooled turbines. Cooled turbines were eliminated from consideration based on a previous analysis which indicated a SFC penalty of 8.9 percent and thrust loss of 18.1 percent for TRIT of $2500^{\circ} \mathrm{F}$. The recuperated cycle was also studied but eliminated from consideration because only small SFC improvements of 4 percent to 9 percent were obtained with thrust losses in the range of 13 percent to 19 percent and engine volume increases up to 200 percent. The optimum cycle parameters for each advanced cycle configuration are:

\begin{tabular}{|c|c|c|c|c|}
\hline & $\begin{array}{r}2-5 p o o 1 \\
\text { Turbof an } \\
\end{array}$ & $\begin{array}{r}\text { 3-Spool } \\
\text { Turbof an } \\
\end{array}$ & $\begin{array}{l}\text { 2-Spool } \\
\text { Propfan } \\
\end{array}$ & $\begin{array}{l}\text { 3-Spool } \\
\text { Propfan } \\
\end{array}$ \\
\hline $\begin{array}{l}\text { TRIT, 'F } \\
\text { OPR } \\
\text { Fan/LP Comp. } \\
\text { IP Comp. }\end{array}$ & $\begin{array}{r}2500 \\
26 \\
1 \text { Axial } \\
-\end{array}$ & $\begin{array}{r}2500 \\
37 \\
1 \text { Axial } \\
1 \text { Axiall } \\
1 \text { Centrifugal }\end{array}$ & $\begin{array}{r}3000 \\
22 \\
1 \text { Axial } \\
\end{array}$ & $\begin{array}{r}3000 \\
45 \\
1 \text { Axial } \\
1 \text { Axial/ } \\
1 \text { Centrif. }\end{array}$ \\
\hline $\begin{array}{l}\text { HP Comp. } \\
\text { HP Turbine } \\
\text { IP Turbine } \\
\text { LP Turbine }\end{array}$ & $\begin{array}{c}2 \text { Centrifugal } \\
1 \text { Radial } \\
2 \text { Axial }\end{array}$ & $\begin{array}{l}1 \text { Centrifugal } \\
1 \text { Radial } \\
1 \text { Radial } \\
3 \text { Axial }\end{array}$ & $\begin{array}{c}2 \text { Centrifugal } \\
1 \text { Raoial } \\
2 \text { Axial }\end{array}$ & $\begin{array}{l}1 \text { Centrit. } \\
1 \text { Radial } \\
1 \text { Radial } \\
3 \text { Axial }\end{array}$ \\
\hline
\end{tabular}

Selection was based on SFC and total stage count because the trade factors indicated SFC as the predominant factor for minimum vehicle weight.

Mission analysis results based on life cycle costs for the reference cruise missile and mission are shown in Figure 17. It should be noted that the reference engine powered cruise missile does not meet the selected reference mission. All advanced technology engine powered cruise missiles meet the reference mission requirements. The range improvement is 40 percent compared to the reference engine. As can be seen from Figure 17, the three-spool propfan has a 41 percent reduction in life cycle cost. This configuration has a 54 percent reduction in fuel burned, and 47 percent reduction in launch vehicle weight compared to the reference engine. The advanced technologies are shown in Figure 18. The required technologies, in order of priority, are lightweight missile propfan gearbox, ceramic/ceramic composite radial turbine, bearings and seals, compressor, and high speed shafts.

\section{Williams International}

Williams International also selected the cruise missile application. Details of the Williams International SECT Study, contract NAS3-24543, are presented in Reference 5. The subsonic strategic mission was selected and potential mission profiles are shown in figure 19. The prime mission selected is the air launch-optimum altitude cruise. The reference cruise missile configuration is shown in Figure 20 . Figureof-merit is life cycle cost. Reference engine has TIT of $1970^{\circ} \mathrm{F}$, overall pressure ratio of 13.6, and is based on current state-of-the-art engine.

Advanced turbofan cycles and recuperated turbofan cycles were investigated for the following parameters: fan pressure ratio from 1.4 to 2.3, overall pressure ratio from 6 to 32 (recuperated cycle 4 to 16 ) and TIT from $1600^{\circ} \mathrm{F}$ to $3200^{\circ} \mathrm{F}$ for uncooled turbines. Recuperator effectivenesses of .65 and .85 were investigated for the recuperated cycle. Based on trade factors of SFC, TIT rise, cost and OPR, the following cycles were selected:

Advanced Turbof an
$\begin{gathered}2200 \\ 3.85 \\ 1.7 \\ 22: 1 \\ -\end{gathered}$

\begin{tabular}{c} 
Recuperated Turbc \\
\hline 2650 \\
3.65 \\
1.7 \\
$8: 1$ \\
.85
\end{tabular}

Figure 21 shows the selected engine configurations for both the recuperated turbof an and advanced simple cycle turbofan. The weight of the recuperator and associated hardware is approximately 1.5 times the advanced turbofan engine weight: This weight increase has to be offset by a significant reduction in fuel burned to compete favorably.

Mission analysis was conducted for recuperated turbofan, advanced simple cycle turbofan, and the reference engine using the reference cruise 
missile and reference missions. All configurations met the range requirements. The mission analysis results are shown in Figure 22 . The recuperated turbofan and advanced turbofan engines had reductions in fuel burned of 47.2 and 38.3 percent respectively compared to the reference engine. However, the advanced turbofan and recuperated turbofan cruise missiles are 28.5 percent and 27.6 percent lighter than the reference engine missile. Reduction in LCC cost is 56 percent for the advanced simple cycle turbofan and 47 percent for the recuperated turbofan compared to the reference engine. Based on LCC costs, the advanced turbofan was selected. Required advanced technologies in order of priority are: solid lubricated bearings; aerodynamics; and ceramic composite materials. Carbon slurry fuels were also investigated and would provide approximately a 10 percent range improvement.

\section{Technology Benefits}

The performance benefits from the Contractor studies have been presented. The reductions in fuel burned for each application are shown in Table I. As can be seen from the table, fuel savings of 22 percent to 42 percent for rotorcraft and commuter applications, and 40 percent to 60 percent for cruise missile applications can be attained by using advanced cycles with projected year 2000 technology component efficiencies and advanced materials.

The resulting reductions in DOC/LCC are shown in Table II. Significant reductions in DOC are obtained at $\$ 1 / \mathrm{gal}$ fuel cost. These reductions are in the range of 6 percent to 16 percent for typical commuter and rotorcraft applications. For $\$ 2 / g a l$ fuel cost, $D O C$ reductions are in the range of 11 percent to 17 percent. For typical cruise missile applications, reductions in life cycle cost of 40 percent to 56 percent are predicted.

TABLE I. - REDUCTION IN FUEL BURNED FOR ALL APPLICATIONS

Fuel Burned Reduction (Percent)

\begin{tabular}{|c|c|c|c|c|}
\hline Contractor & Commuter & Rotorcraft & APU & Cruise Missile \\
\hline $\begin{array}{l}\text { Allison } \\
\text { AVCO Lycoming }\end{array}$ & 38.3 & 30.1 & & \\
\hline Garrett & 35.0 & $\begin{array}{l}21.9 \\
41.6\end{array}$ & $\begin{array}{l}43.2 \\
70.8\end{array}$ & \\
\hline $\begin{array}{l}\text { Teledyne } \\
\text { Williams }\end{array}$ & & & & $\begin{array}{l}54.0 \\
38.3\end{array}$ \\
\hline
\end{tabular}

TABLE II. - DOC/LCC BENEFIT FOR EACH APPLICATION

DOC/LCC Reductions (Percent)

\begin{tabular}{|c|c|c|c|c|c|c|c|}
\hline Contractor & \multicolumn{2}{|c|}{ Comuter } & \multicolumn{2}{|c|}{ Rotoreraft } & \multicolumn{2}{|c|}{ APS } & $\begin{array}{l}\text { Cruise } \\
\text { Missile }\end{array}$ \\
\hline $\begin{array}{l}\text { Allison } \\
\text { AVCO Lycoming }\end{array}$ & 12.5 & 17.0 & 16.5 & 17.4 & & & \\
\hline Garrett & 5.7 & & $\begin{array}{l}7.0 \\
7.4\end{array}$ & $\begin{array}{r}8.7 \\
11.4\end{array}$ & $\begin{array}{l}36.7 \\
39.0\end{array}$ & $\begin{array}{l}38.3 \\
47.0\end{array}$ & \\
\hline $\begin{array}{l}\text { Teledyne } \\
\text { williams }\end{array}$ & & & & & & & $\begin{array}{l}41 \\
56\end{array}$ \\
\hline
\end{tabular}

TABLE III. - CONTRACTOR TECHNOLOGY RANKINGS BASED ON DOC OR LCC

\begin{tabular}{|c|c|c|c|c|c|c|c|c|}
\hline & \multicolumn{6}{|c|}{ ROTORCRAFT/COMMUTER } & \multicolumn{2}{|c|}{ CRUISE MISSILE } \\
\hline & \multicolumn{2}{|c|}{ ALLISON } & \multicolumn{2}{|c|}{$\begin{array}{l}\text { AVCO } \\
\text { LYCOHING }\end{array}$} & \multicolumn{2}{|c|}{ GARRETI } & \multirow[t]{2}{*}{$\begin{array}{l}\text { TELE- } \\
\text { OYNE }\end{array}$} & \multirow{2}{*}{ WILLIAMS } \\
\hline & S1/6At & S2/GAL & S1/GAL & $\$ 216 \mathrm{AL}$ & $\$ 51 / 6,16$ & 521646 & & \\
\hline $\begin{array}{l}\text { MATERIALS } \\
\text { CERAMICS }\end{array}$ & 582 & $57 \%$ & 652 & 552 & $45:$ & 408 & 318 & 231 \\
\hline AOVANCEO METALLIC DISK & & & & & $20:$ & 31 & & \\
\hline $\begin{array}{l}\text { AOVANCED AERODYNAMICS } \\
\text { 3-0 COOES ANO COMPONENTS }\end{array}$ & 40: & 421 & 298 & $25:$ & 308 & 348 & $22 t$ & 248 \\
\hline TLRBINE & 172 & 188 & 118 & 108 & 171 & 178 & 157 & 122 \\
\hline $\begin{array}{l}\text { COMPRESSOR } \\
\text { COMQUSTOR }\end{array}$ & $\begin{array}{r}14 ! \\
91\end{array}$ & $\begin{array}{r}15 \pi \\
98\end{array}$ & $18 x$ & 152 & 101 & 148 & 78 & 127 \\
\hline RECUPERATOR & & & 62 & 208 & & 228 & & \\
\hline SYSTEMS TECHNOLOGIES & & & & & & & & \\
\hline $\begin{array}{l}\text { BEARINGS } \\
\text { SHMFTS }\end{array}$ & - & - & & & • & - & " & $45 \rrbracket$ \\
\hline $\begin{array}{l}\text { SHAFTS } \\
\text { SEALS }\end{array}$ & & & & & : & : & - & \\
\hline GEARBOX & & & & & & & 408 & \\
\hline SLLRRY FUEL COHQUSTOR & & & & & & & ". & 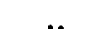 \\
\hline
\end{tabular}

- necessury to achieve gains from materials ano aerooynamics

- CRUISE MISSILE RANGE BENEFIT

To achieve the significant reductions in $\mathrm{DOCl}$ LCC indicated in the studies, the following high payoff technologies were identified and ranked by benefits: 1. advanced materials ceramic/ceramic composites, and advanced metallic disk; 2. advanced aerodynamics - highly efficient components, and three-dimensional viscous codes; 3 . lightweight compact recuperator; and 4. system technologies - bearings, seals, gearbox, and metal matrix shafts. For the cruise missile applications, the system technologies were ranked first followed by advanced materials and advanced aerodynamics.

The contractor technology rankings for rotorcraft/comuter and cruise missile applications are snown in Table III. The technologies are ranked on cost benefit based on direct operating cost or life cycle cost. As can be seen from Table III, for the rotorcraft/commuter application, the high payoff technologies in order of priority are: 1. advanced materials which provide 43 percent to 65 percent of the cost benefit; 2. advanced aerodynamics which provide 25 percent to 40 percent of the cost benefit; and 3 . recuperator which provides 0 percent to 22 percent of the cost benefit. Materials and advanced aerodynamics provide significant cost benefit irrespective of the fuel cost. The recuperator, however, pays off at $\$ 2 / g a l$ for the cycles selected. In the Garrett study however, if the advanced metallic disk technology is not achieved, a recuperator is required and the cost benef it of the technologies for $\$ 1 / \mathrm{gal}$ fuel turns out to be the same as the cost benefit for $\$ 2 / g a l$ recuperated cycle. The system technologies are necessary to achieve the gains from the advanced materials and aerodynamics.

For the subsonic strategic cruise missile application, the nigh payoff technologies in order of priority are: 1 . system technologies 
which provide approximately 40 percent of the cost benefit; 2 . advanced materials which provide 23 percent to 31 percent of the cost benefit and 3. aerodynamics which provide approximately 23 percent of the cost benefit.

\section{Concluding Remarks}

The SECT contractor studies, aimed at identifying high payoff technologies for small gas turbine applications, are described in this paper. Study results are quite comprehensive in detailing approaches for achieving technology readiness for efficient small engines by year 2000. Taken in total, the results clearly indicate a prioritized order of nigh payoff technologies, as is shown in Table III.

Concurrent with the contracted studies, additional in-house NASA/Army cycle studies were undertaken at the Lewis Research Center. The in-house study results agree, in all important aspects, with the Contractor's results. Thus, the program approaches appear well defined.

In using the studies to formulate an overall program plan, several assumptions were made. These are: 1. The research must be revolutionary, not evolutionary in nature. By that, it is meant that incremental gains, forseeable as natural evolution of the state-of-the-art will not be the basis of the program; 2. Other government research programs, at NASA as well as at other federal agencies, will be utilized to achieve program goals; and 3. Generic technologies, applicable to multiple mission needs will be favored over technologies restricted to single missions, but not exclusively so.

Although specific program plans and their implementation await funding decisions currently in progress, the following comments on the technologies listed in Table III appear relevant. Materials research will be aimed at increasing hot-section operating temperatures to $2600^{\circ} \mathrm{F}-2800^{\circ} \mathrm{F}$ levels while, at the same time, minimizing or eliminating required coolant flow. Much industry and government work evolving ceramics and ceramic composite materials is currently in progress. Program efforts will supplement these efforts where appropriate, commensurate with available funding. Additional research will be undertaken to evolve design codes and component configurations to fully utilize these materials.

Advanced aerodynamics research encompasses two areas: 1. the evolution, verification and development of fully three-dimensional viscous design codes; and 2 . the identification and evaluation of advanced component concepts. Elimination of turbomachinery stages, efficient radial and axial turbine designs and compressor efficiency improvement of 5 to 10 points, dependent on size, will be pursued. Combustor research will focus on the elimination of coolant flows and reouctions of exit temperature maldistributions to one-half currently achievable levels.
Significant technological breakthroughs are required in heat exchangers for aeronautical applications. Currently, required weight, volume, efficiency and pressure loss trade-offs negate much of the fuel saving gains sought in recuperative/regenerative engine cycles. Application of ceramic substrates coupled with better understandings of heat transfer through porous media could permit optimization of these cycles.

Evolution of the technologies described above will lead to major advances in small engine powerplants, and could lead to new generations of aircraft with greatly expanded capabilities for both civil and military missions.

\section{References}

1. Larkin, T., Staton, D. and Mongia, H., "Rotorcraft Propulsion for Year 2000 Plus," AIAA Paper No. 86-1543, to be presented at the AIAA/ASME/SAE/ ASEE 22nd Joint Propulsion Conference, Huntsville, Alabama, June $16-18,1986$.

2. Kaehler, H. and Schneider, W., "Small Engine Technology Payoffs for Future Cormuter Aircraft," AIAA Paper No. 86-1544, to be presented at the AIAA/ ASME/SAE/ASEE 22nd Joint Propulsion Conference, Huntsville, Alabama, June 16-18, 1986.

3. Turk, M. and Zeiner, P., "Advanced Technology Payoffs for Future Rotorcraft, Commuter Aircraft, Cruise Missile and APU Propulsion Systems," AIAA Paper No. 86-1545, to be presented at the AIAA/ASME/SAE/ASEE 22nd Joint Propulsion Conference, Huntsville, Alabama, June 16-18, 1986.

4. Singh, B. and Benstein, E., "Year 2000 Small Engine Technology Payoffs in Cruise Missiles," AIAA Paper No. 86-1546, to be presented at the AIAA/ ASME/SAE/ASEE 22nd Joint Propulsion Conference, Huntsville, Alabama, June 16-18, 1986.

5. Pampreen, R., "Engine Studies for Future Subsonic Cruise Missiles," AIAA Paper No. 86-1547, to be presented at the AIAA/ASME/ SAE/ASEE 22nd Joint Propulsion Conference, Huntsville, Alabama, June 16-18, 1986. 


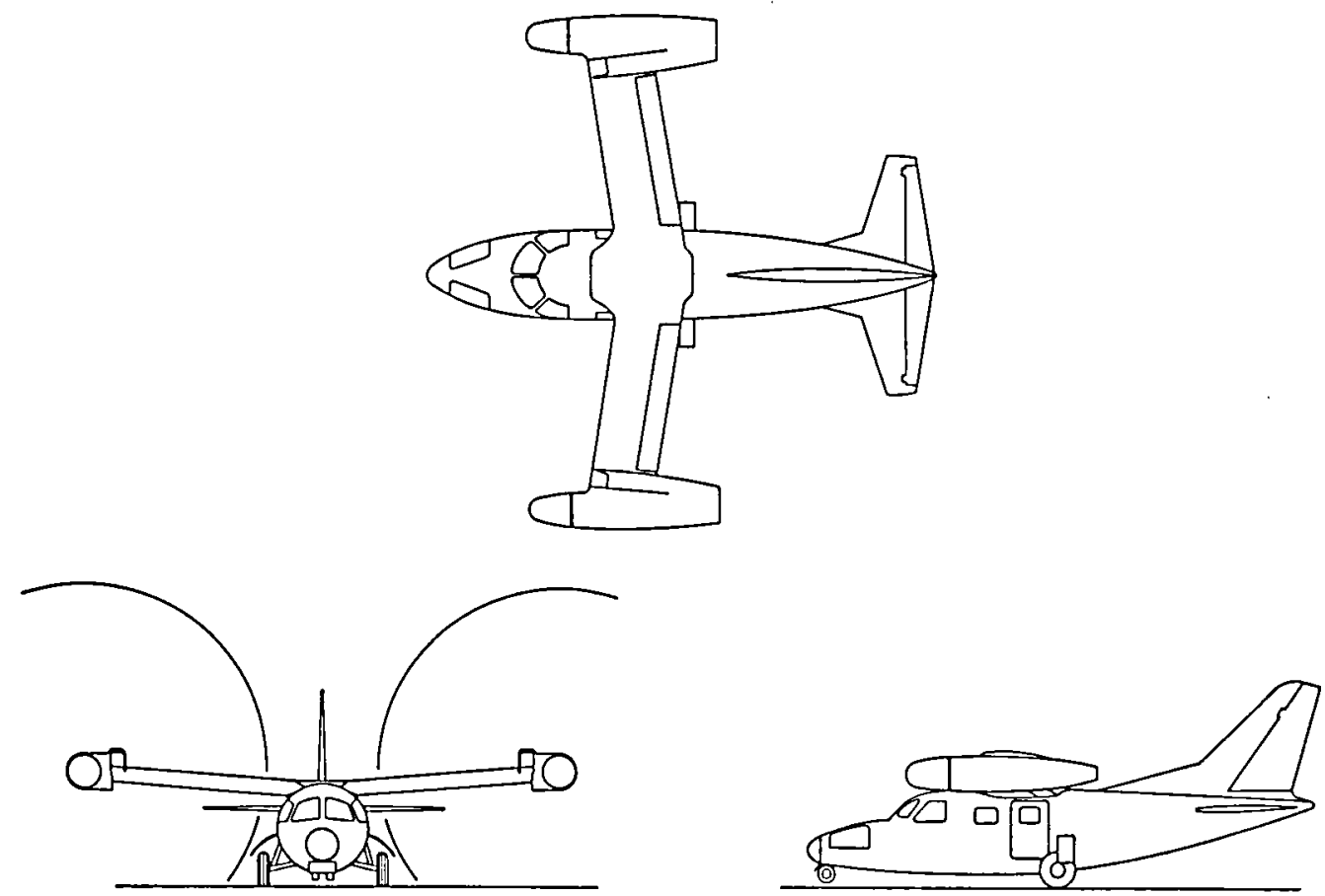

FIGURE 1. - ALLISON REFERENCE TILT ROTOR AIRCRAFT (3-VIEW DRAWING)

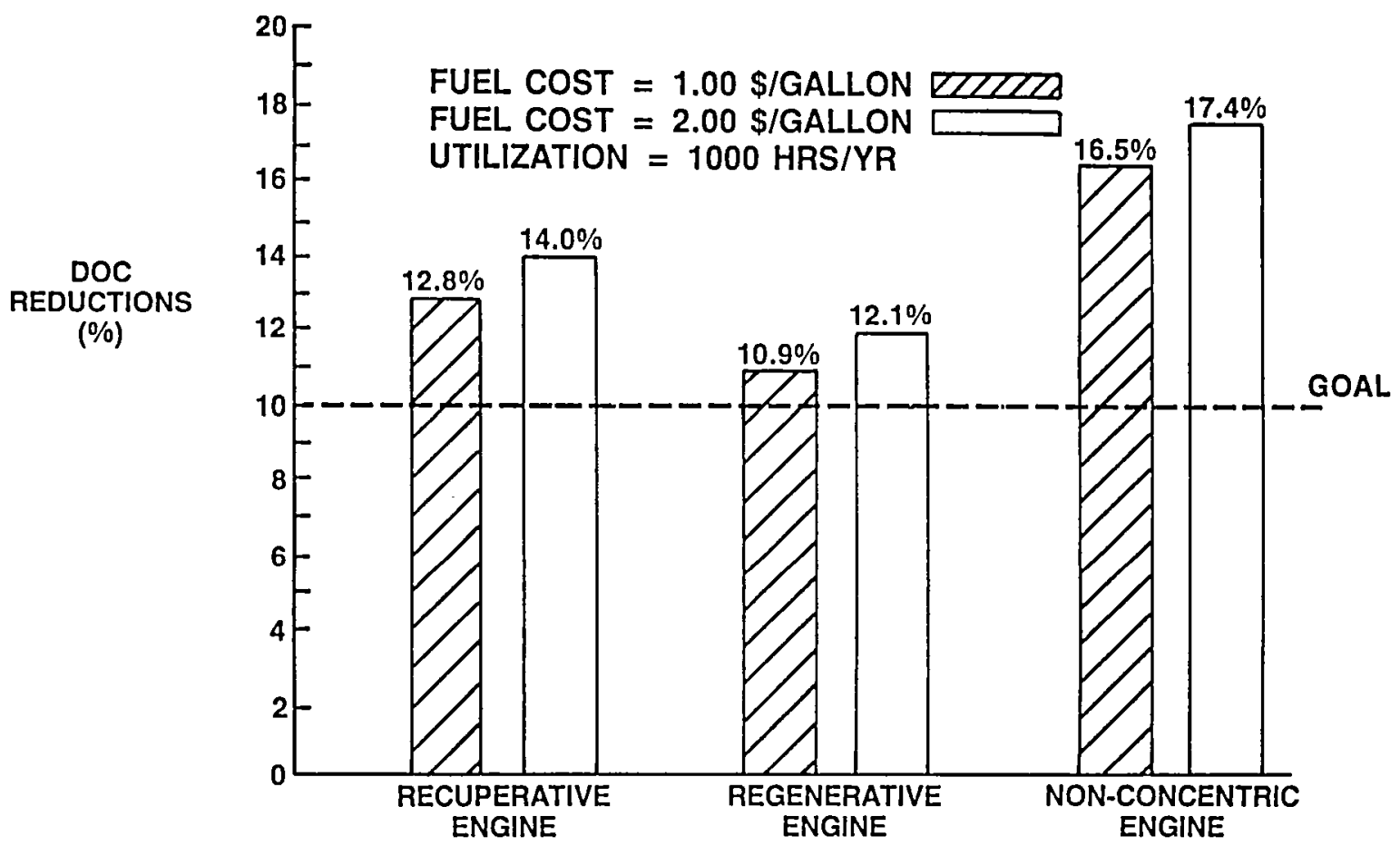

FIGURE 2. - ALLISON MISSION ANALYSIS RESULTS FOR ADVANCED ENGINE CONFIGURATIONS 

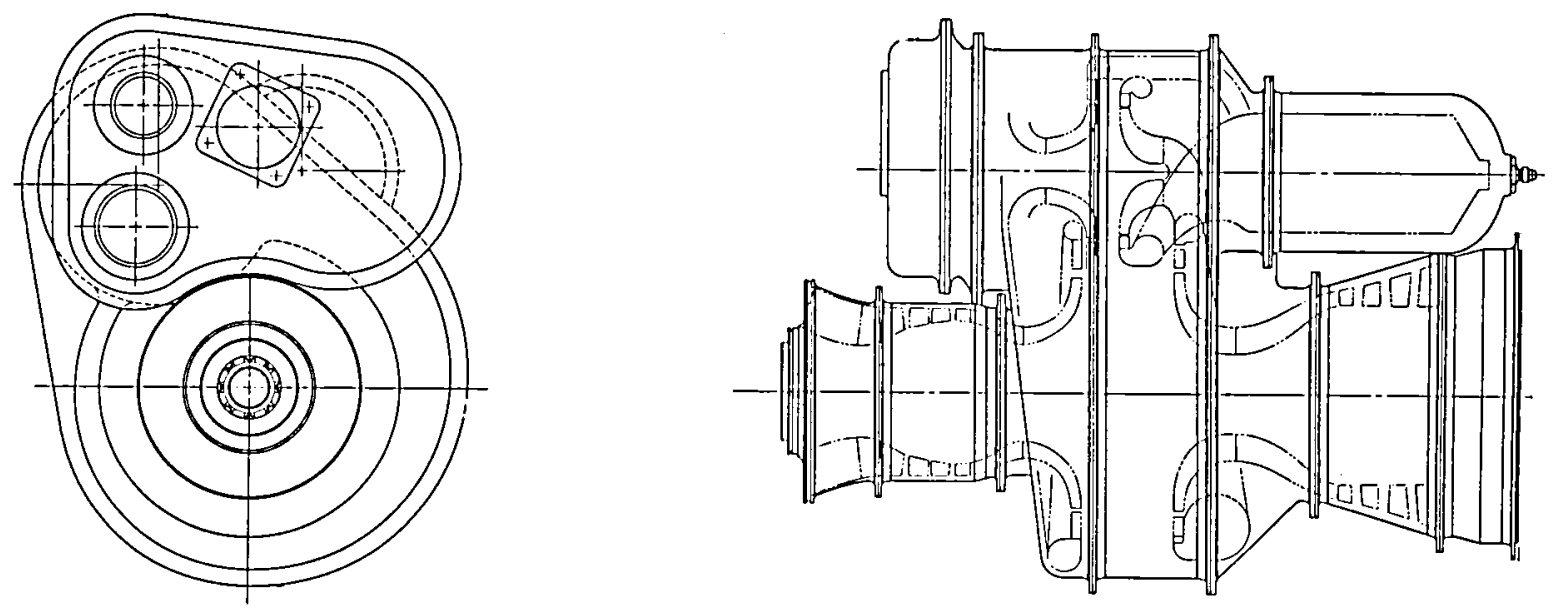

FIGURE 3. - ALLISON NON-CONCENTRIC ENGINE GENERAL ARRANGEMENT

- 19 Passenger Pressurized

- Engines: Twin 960 HP Turboprops

- Weight: $12,930 \mathrm{lb}$ TOGW 11,138 lb Zero-Fuel

- Wing Loading: 50.7 psi 9.8 Aspect Ratio

- cruise $I^{\prime} b_{2} 8.3$
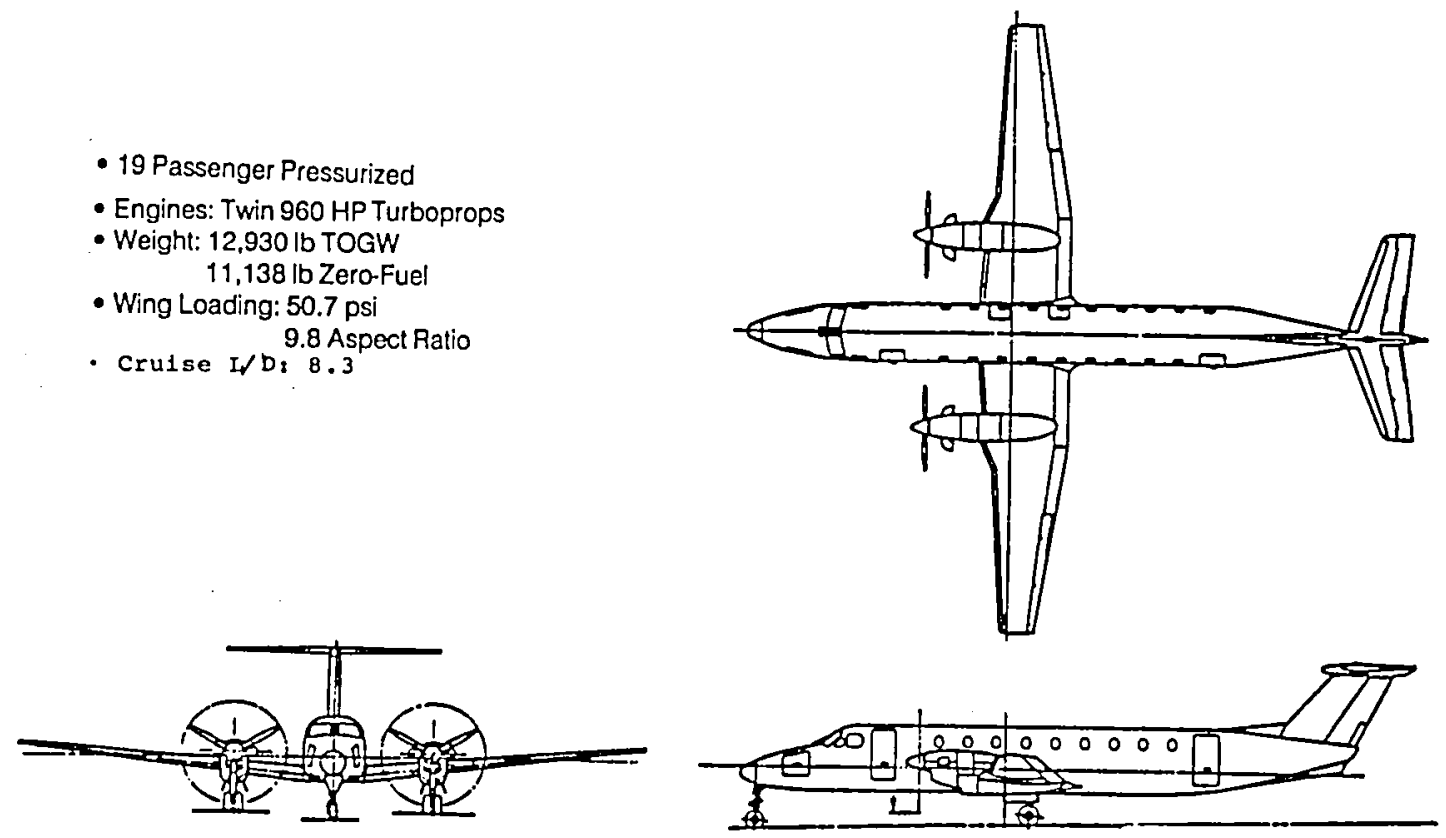

FIGURE 4. - LYCOMING REFERENCE COMMUTER AIRCRAFT 
A/C SENSITIVITY TO RECUPERATOR EFFECTIVENESS TWO-PASS HEAT EXCHANGER

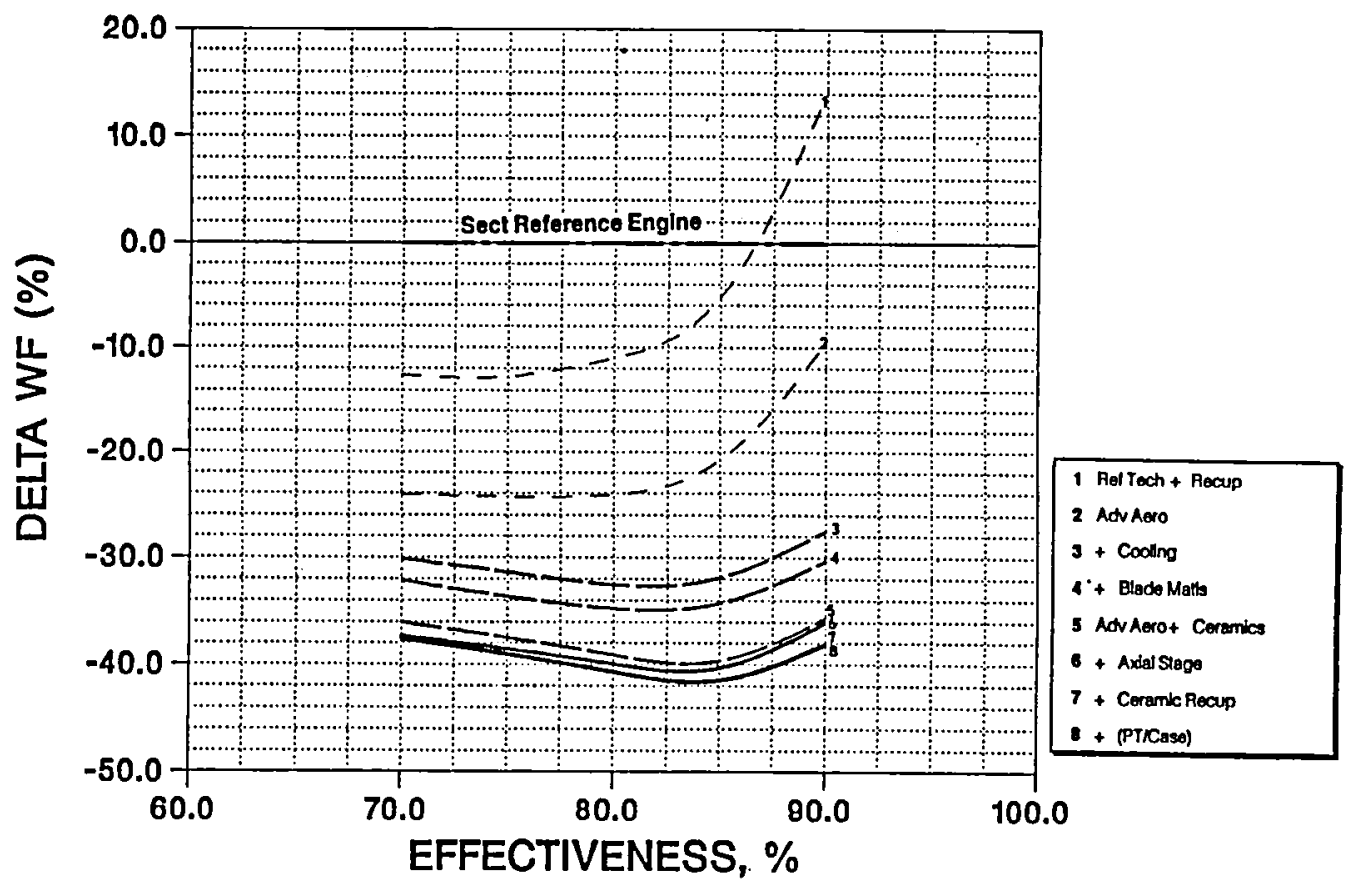

FIGURE 5. - LYCOMING AIRCRAFT $\triangle$ FUEL BURNED RESULTS

\section{A/C SENSITIVITY TO RECUPERATOR EFFECTIVENESS TWO-PASS HEAT EXCHANGER $2.00 \$ / G A L L O N$}

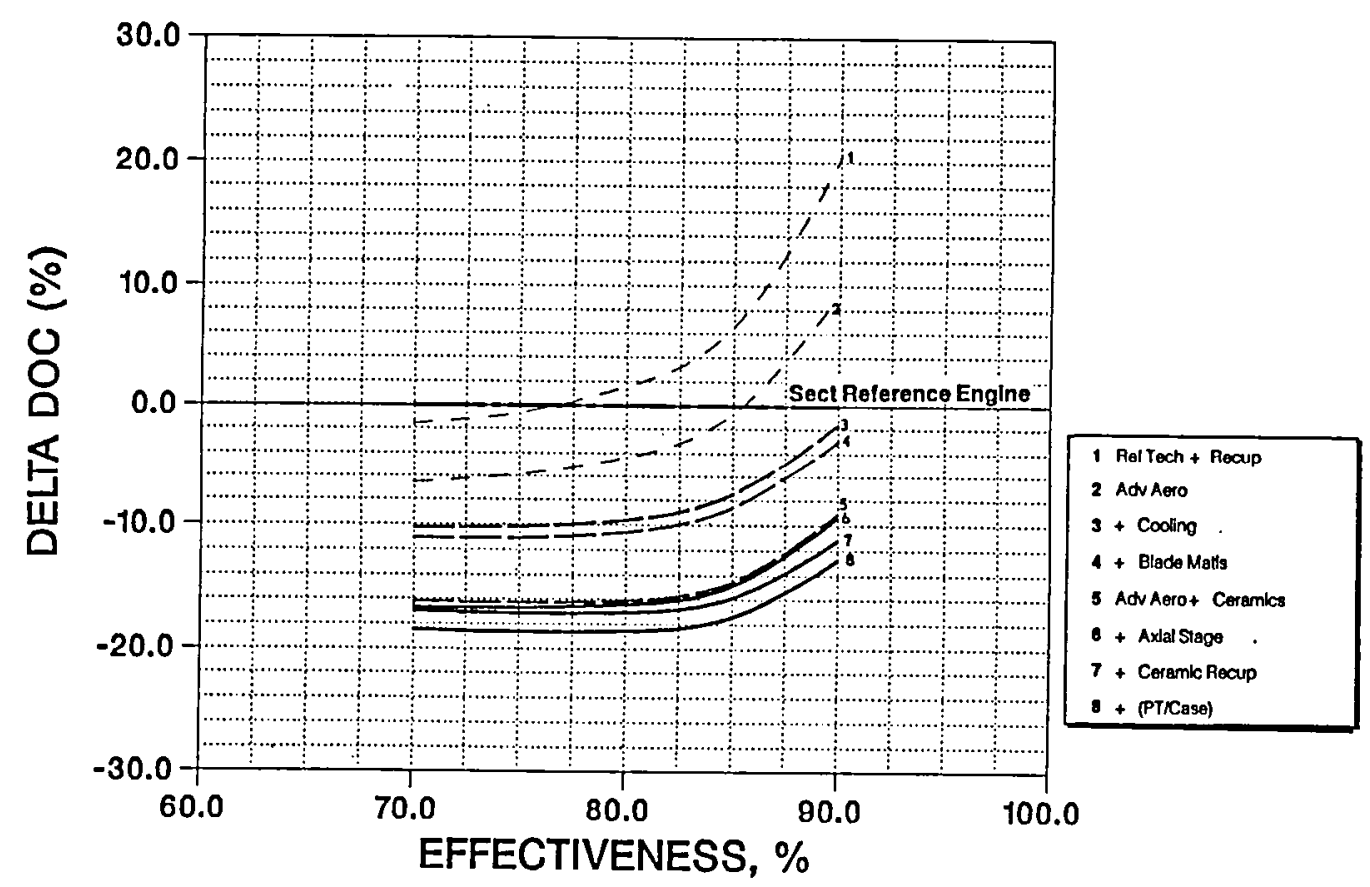

FIGURE 6. - LYCOMING $\triangle$ DOC RESULTS FOR \$2/GALLON FUEL COST 


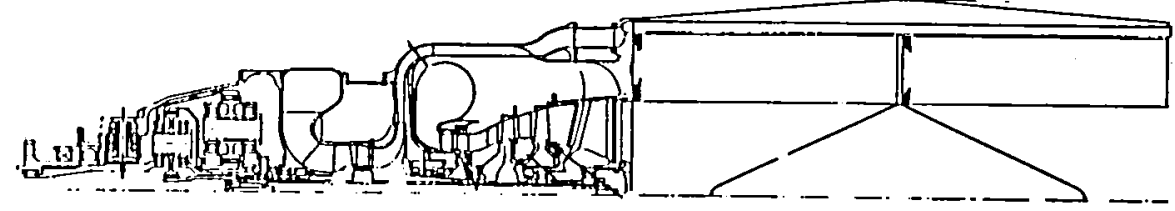

FIGURE 7. - LYCOMING RECUPERATEO ENGINE CONFIGURATION

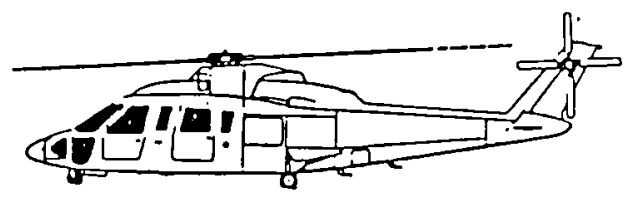

- TWIN ENGINE (1000 SHP EACH)

- WEIGHTS

- EMPTY - 4375 LB

- FUEL - 1303 LB

- PAYLOAD - 3676 LB

- TOGW (INCLUDES PILOT WEIGHT OF 210 LB) - 9564 LB

FIGURE 8. - GARRETT REFERENCE ROTORCRAFT

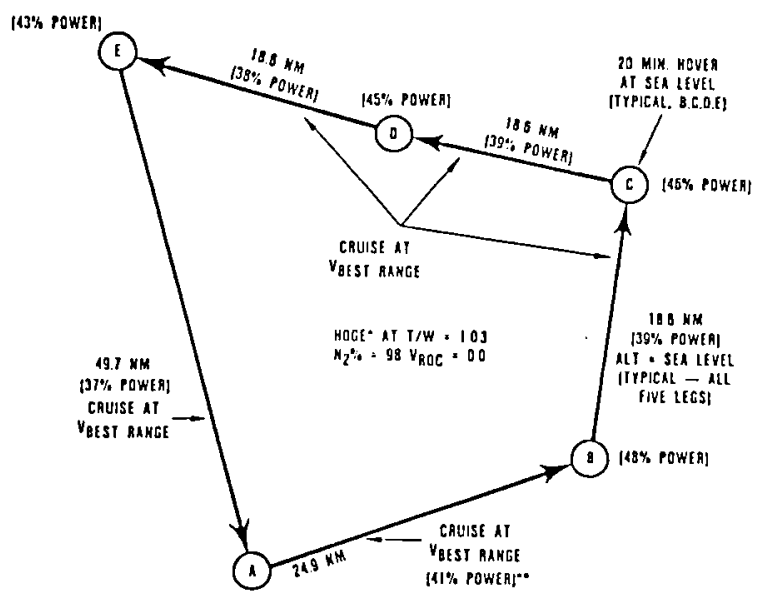

MISSION LENGTH: $130.4 \mathrm{NM}$ MISSION TIMES:

HOVER - 1 HOUR, 20 MINUTES

CRUISE - 59 MINUTES

BLOCK -2 HOURS, 19 MINUTES 


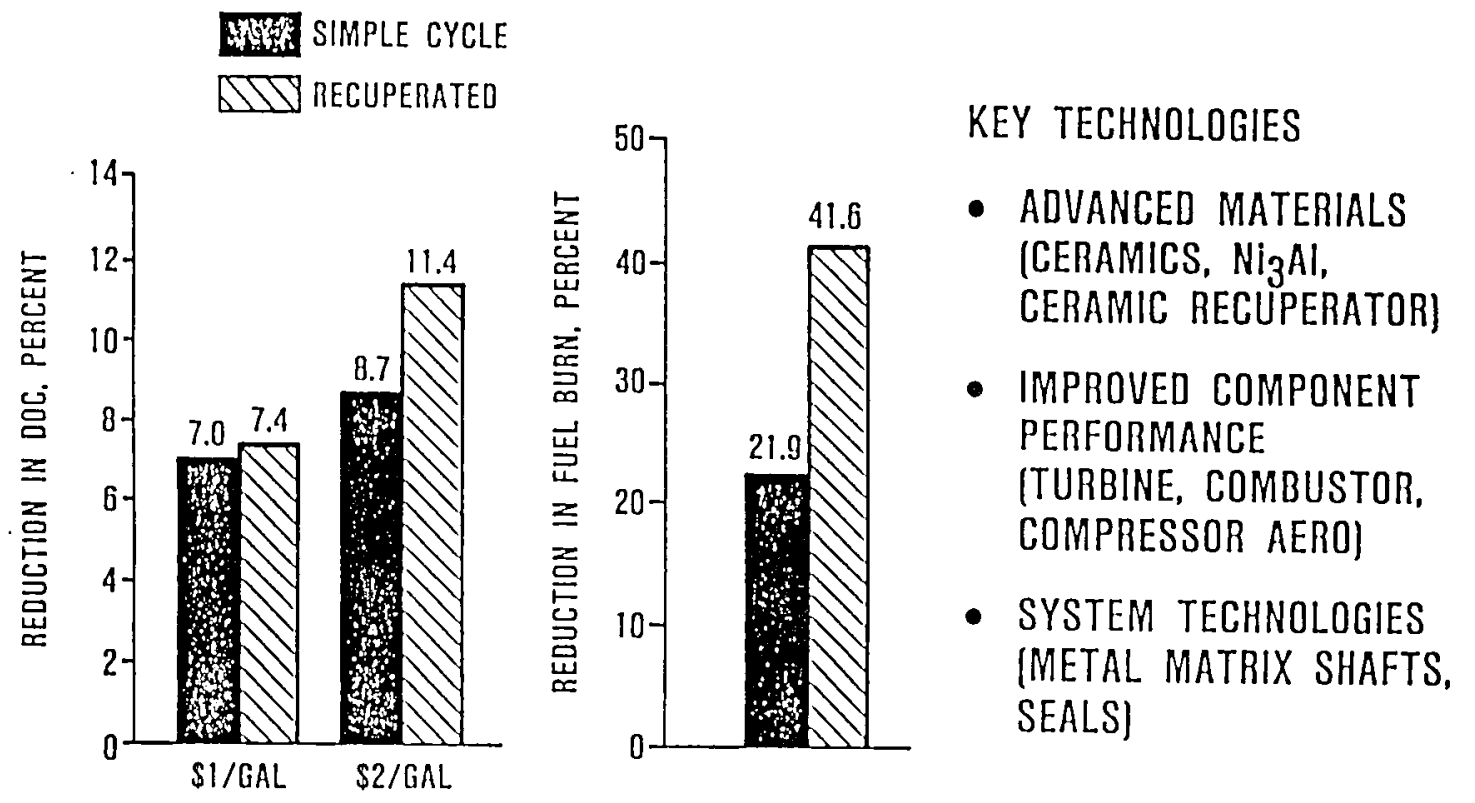

FIGURE 10. - GARRETT MISSION ANALYSIS RESULTS FOR ROTORCRAFT APPLICATION

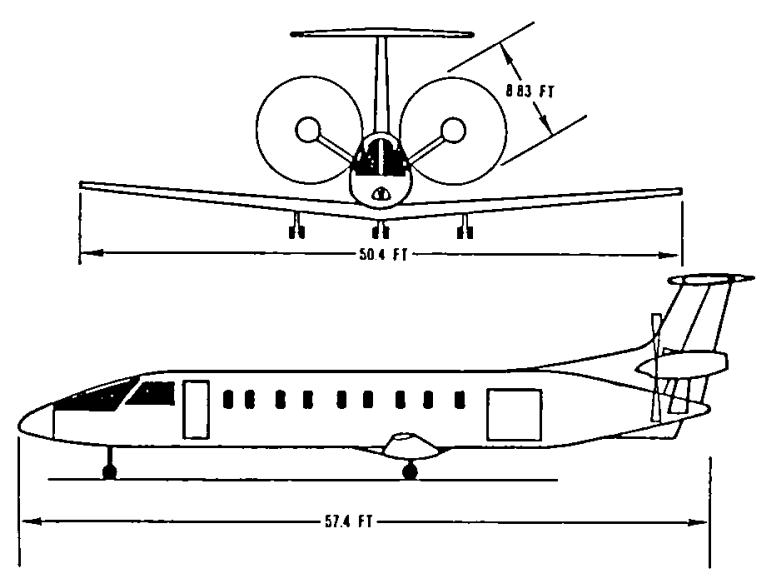

- 19 PASSENGers

- TWIN ENGINE (1000 SHP EACH)

- CRUISE L/D = 7 TO 8

- EMPTY WEIGHT = 6808 LBS

- OWE $=7370$ LBS

- PAYLOAD = 3610 LBS

- FUEL = 2100 LBS

- TOGW $=13,080$ LBS

FEATURES

- BONDED ALUMINUM LITHIUM ALLOYS - FUSELAGE

- COMPOSITES - EMPENNAGE, NACELLES, MAIN WING

FIGURE 11. - GARRETT REFERENCE COMMUTER AIRCRAFT 


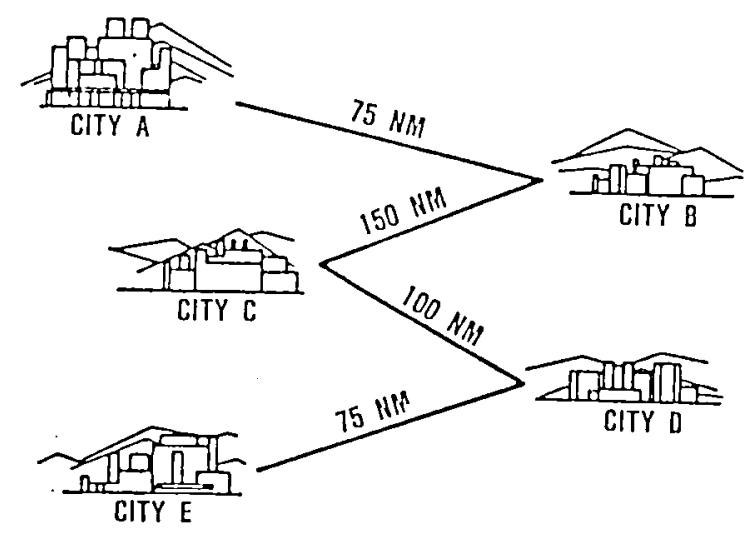

\begin{tabular}{|c|c|c|c|}
\hline $\begin{array}{c}\text { ORIGIN } \\
\text { DESTINATION }\end{array}$ & $\begin{array}{c}\text { SYAGE } \\
\text { DISTANCES, } \\
\text { NAUTICAL } \\
\text { MILES }\end{array}$ & $\begin{array}{c}\text { PASSENGERS } \\
\text { CARRIED }\end{array}$ & $\begin{array}{c}\text { CRUISE } \\
\text { SPEED }\end{array}$ \\
\hline A-B & 75 & 19 & 254 \\
B.C & 150 & 19 & 255 \\
C.D & 100 & 19 & 255 \\
D-E & 75 & 19 & 255 \\
\hline
\end{tabular}

- max cruise power

- cruise altitude = $8000 \mathrm{FT}$

- total distance $=400 \mathrm{NM}$

- FUEL CAPACITy = 2100 LBS

- BLOCK FUEL $=1801$ LBS

- BLOCK TIME $=2$ HOURS, 37 MINUTES

*INCLUDES 45 MINUTE/RESERUE

FIGURE 12. - GARRETT MISSION FOR COMMUTER APPLICATION

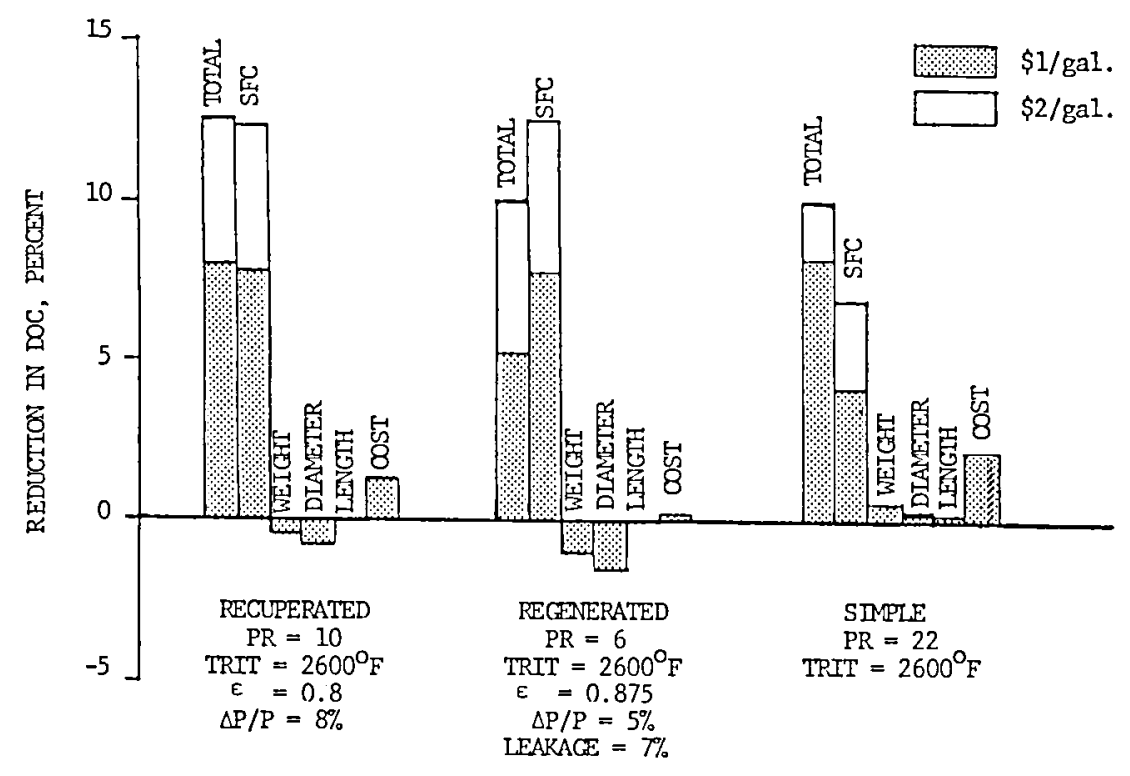

FIGURE 13. - GARRETT ENGINE CYCIE SELECTION FOR COMMUIER APPLICATION 

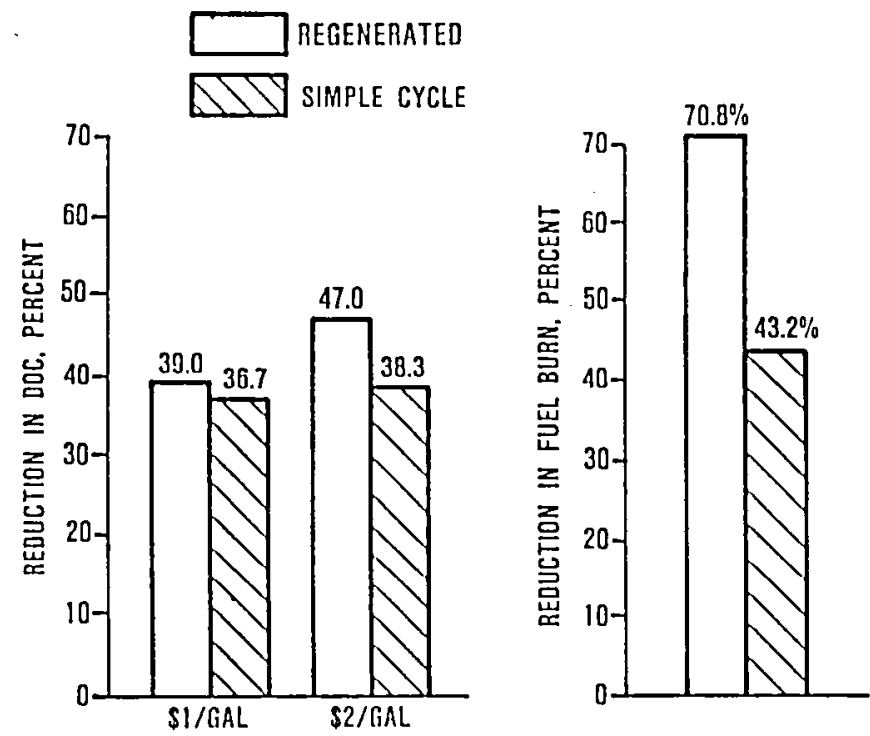

KEY TECHNOLOGIES

- ADVANCED MATERIALS (CERAMICS, CERAMIC REGENERATOR)

- IMPROVED COMPONENT PERFORMANCE (TURBINE, COMBUSTOR, COMPRESSOR AERO)

- SYSTEM TECHNOLOGIES IMETAL MATRIX SHAFTS, SEALS]

FIGURE 14. - GARRETT APU MISSION ANALYSIS RESULTS

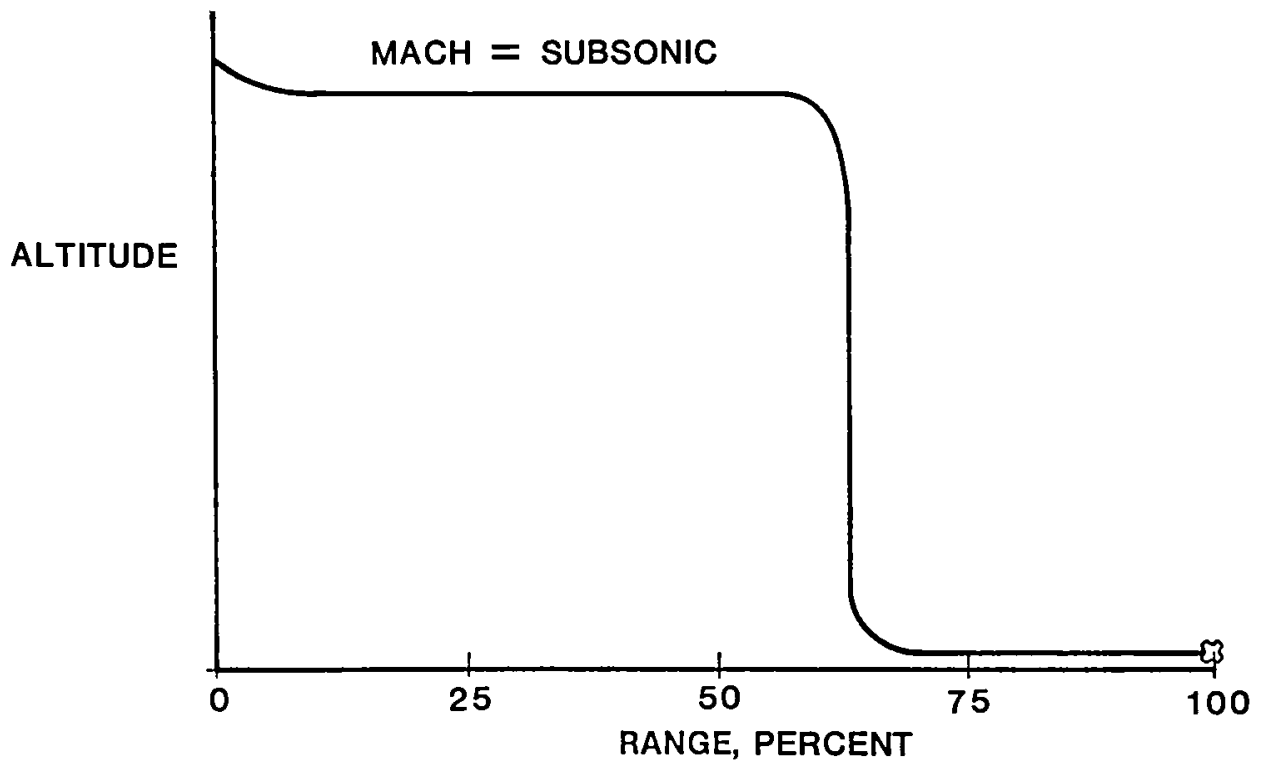

FIGURE 15. - TELEDYNE MISSION FOR CRUISE MISSILE APPLICATION 

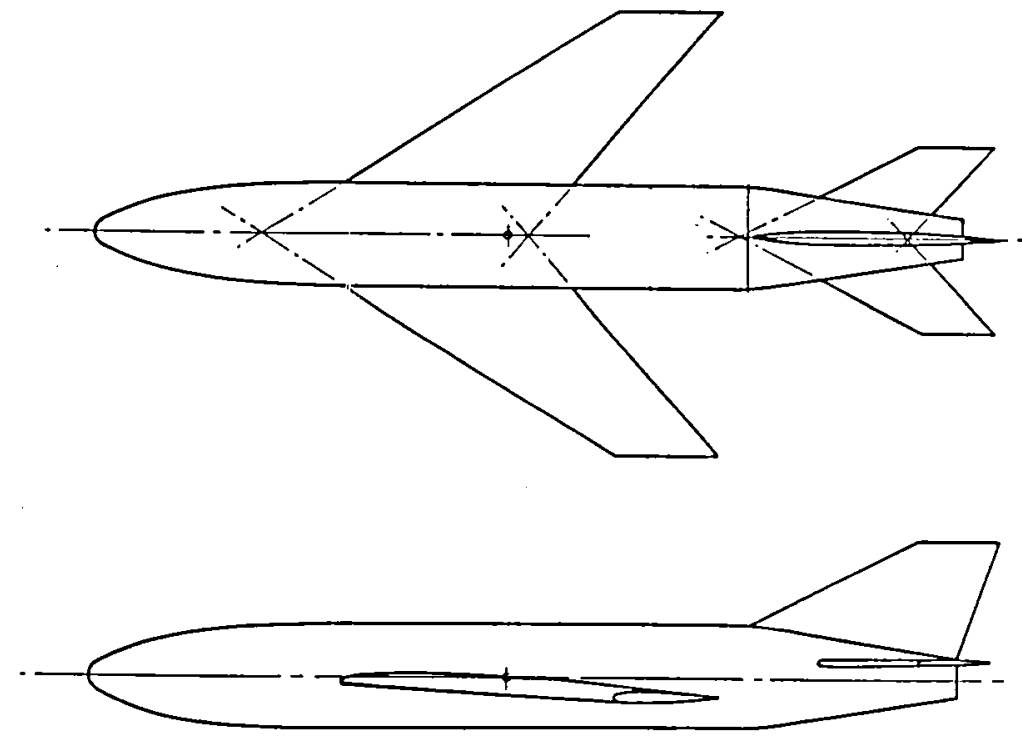

FIGURE 16. - TELEDYNE REFERENCE CRUISE MISSILE CONFIGURATION

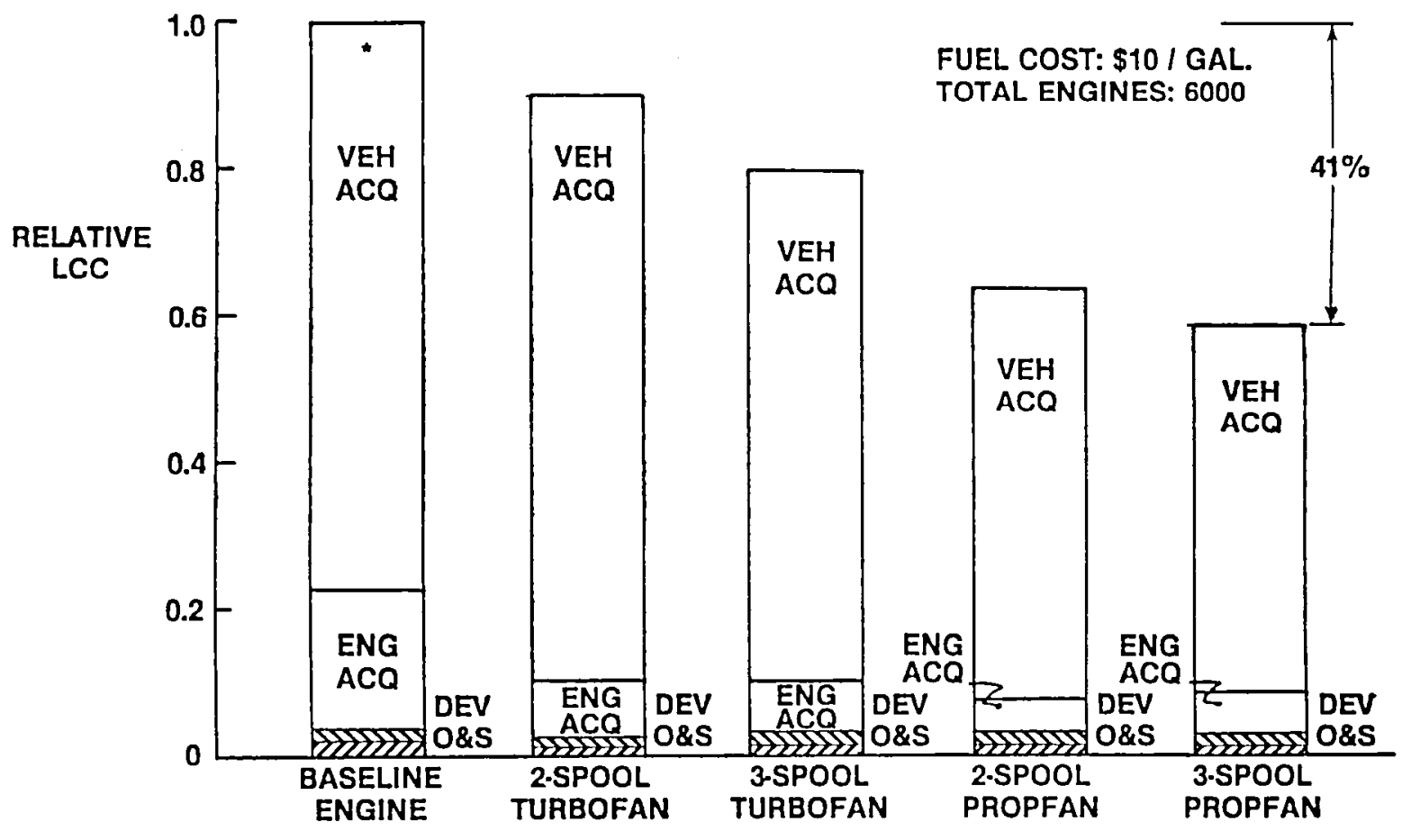

"DOES NOT MEET MISSION

FIGURE 17. - TELEDYNE SYSTEM LIFE CYCLE COST RESULTS 


\begin{tabular}{|c|c|c|}
\hline RANK/BENEFITS & PROGRAM & RISK \\
\hline $\begin{array}{l}1 \\
\text { INCIDENTAUAVAILABLE }\end{array}$ & $\begin{array}{l}\text {-MIXER NOZZLE, FUEL CONTROL, } \\
\text { PROPFANS, COMPOS. COLD STATIC }\end{array}$ & \\
\hline 2 NOT VERY IMPORTANT & $\begin{array}{l}\text { - LP TURBINE } \\
\text { - FAN/LP COMPRESSOR }\end{array}$ & LOW \\
\hline $\begin{array}{l}3 \\
\text { IMPORTANT }\end{array}$ & $\begin{array}{l}\text { - LO. COATINGSIMATERIALS } \\
\text { - INSTRUMENTATION }\end{array}$ & MODERATE \\
\hline $\begin{array}{l}4 \\
\text { VERY IMPORTANT }\end{array}$ & $\begin{array}{l}\text { - DOUBLE CENTRIFUGAL COMPRESSOR } \\
\text { - AXI.CENTRIFUGAL COMPRESSOR } \\
\text { - SLINGER COMBUSTOR } \\
\text { - SHAFTS (HIGH SPEED AND HIGH LOAD) }\end{array}$ & HIGH \\
\hline $\begin{array}{l}5 \\
\text { MANDATORY }\end{array}$ & $\begin{array}{l}\text { - CERAMIC COMPOSITE RADIAL TURBINE }\left(3000^{\circ} \mathrm{F}\right) \\
\text { - BEARINGSISEALS (1200 } \mathrm{F}) \\
\text { - LIGHT WT. MISSILIZED PROPFAN GEARBOX }\end{array}$ & VERY HIGH \\
\hline
\end{tabular}

FIGURE 18. - TELEDYNE TECHNOLOGY IDENTIFICATION AND RANKING

SUBSONIC STRATEGIC
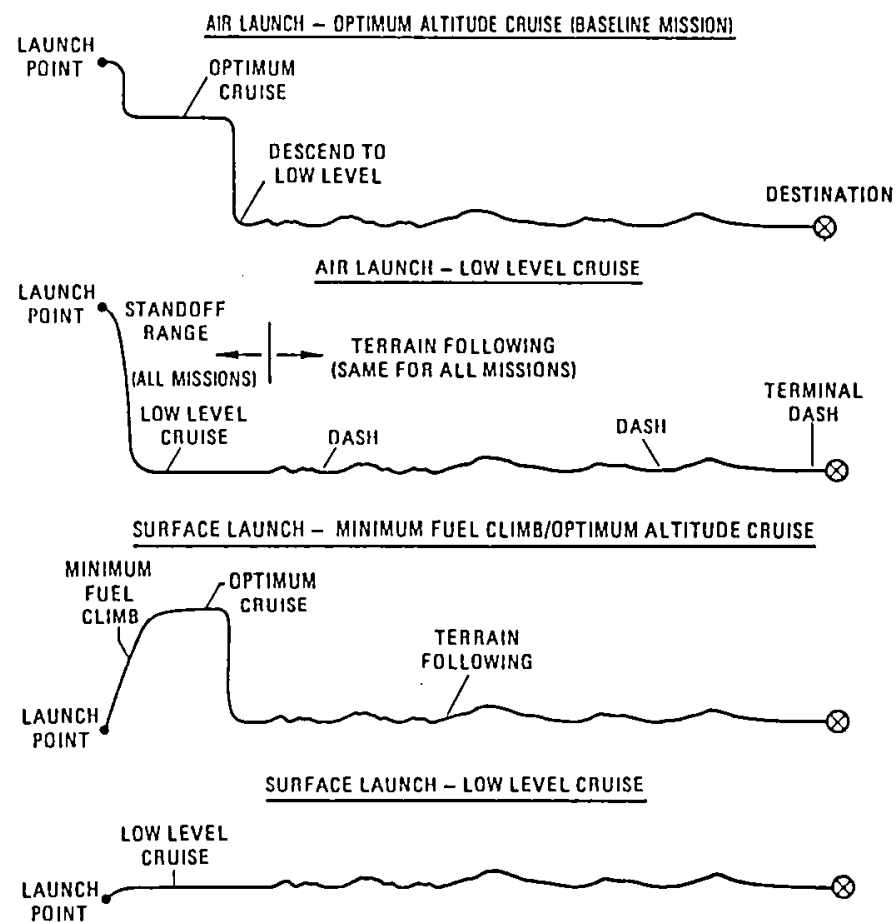

FIGURE 19. - WILLIAMS MISSIONS FOR CRUISE MISSILE APPLICATION 


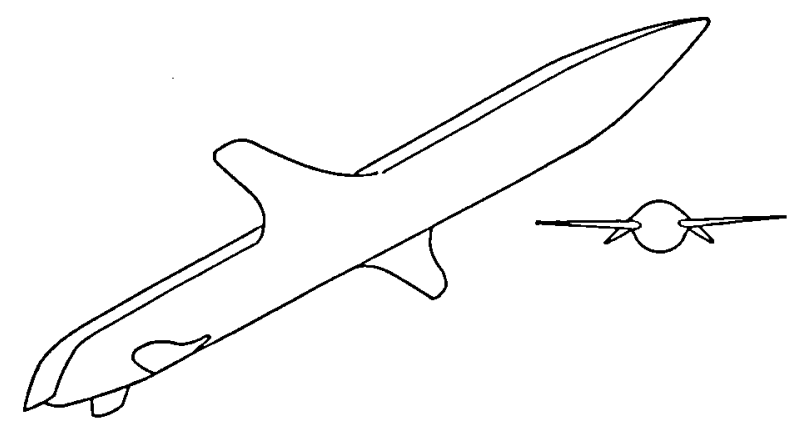

FIGURE 20. - WILLIAMS REFERENCE CRUISE MISSILE CONFIGURATION

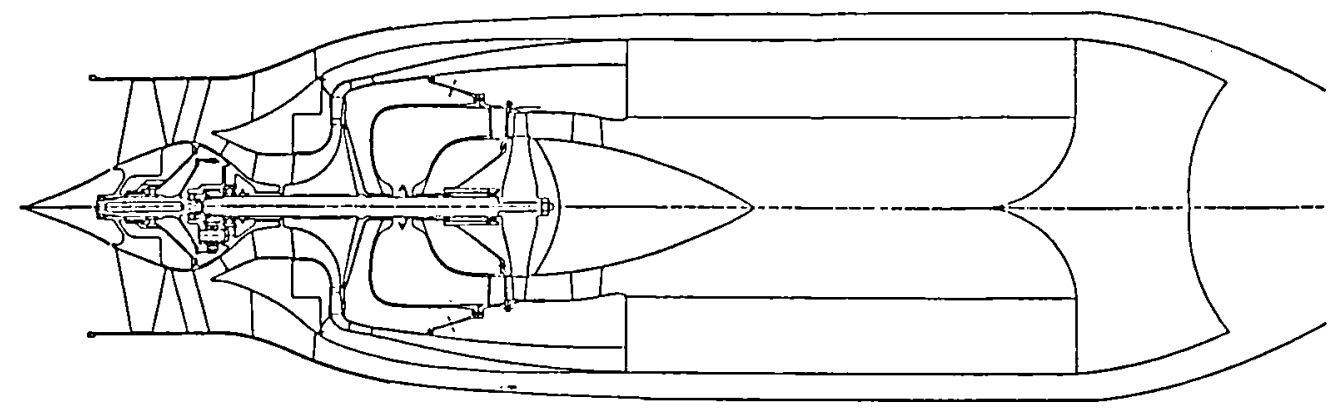

RECUPERATED TURBOFAN

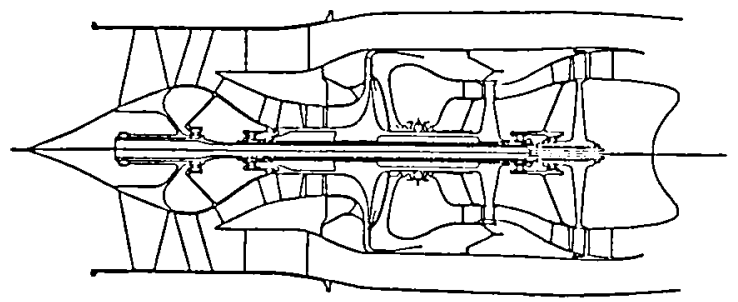

ADVANCED TURBOFAN

FIGURE 21. - WILLIAMS CRUISE MISSILE ENGINE CONFIGURATIONS 
REFERENCE MISSILE WITH ADVANCED ENGINE COMPARED

TO REFERENCE ENGINE

GROSS WEIGHT:

ADVANCED TURBOFAN

$-28.5 \%$

ADVANCED RECUPERATED

$-27.6 \%$

FUEL BURNED:

ADVANCED TURBOFAN

$-38.3 \%$

ADVANCED RECUPERATED

$-47.2 \%$

LIFE CYCLE COST:

ADVANCED TURBOFAN

$-56.0 \%$

ADVANCED RECUPERATED

$-47.0 \%$

FIGURE 22. - WILLIAMS MISSION ANALYSIS RESULTS FOR ADVANCED TECHNOLOGY RANKINGS 


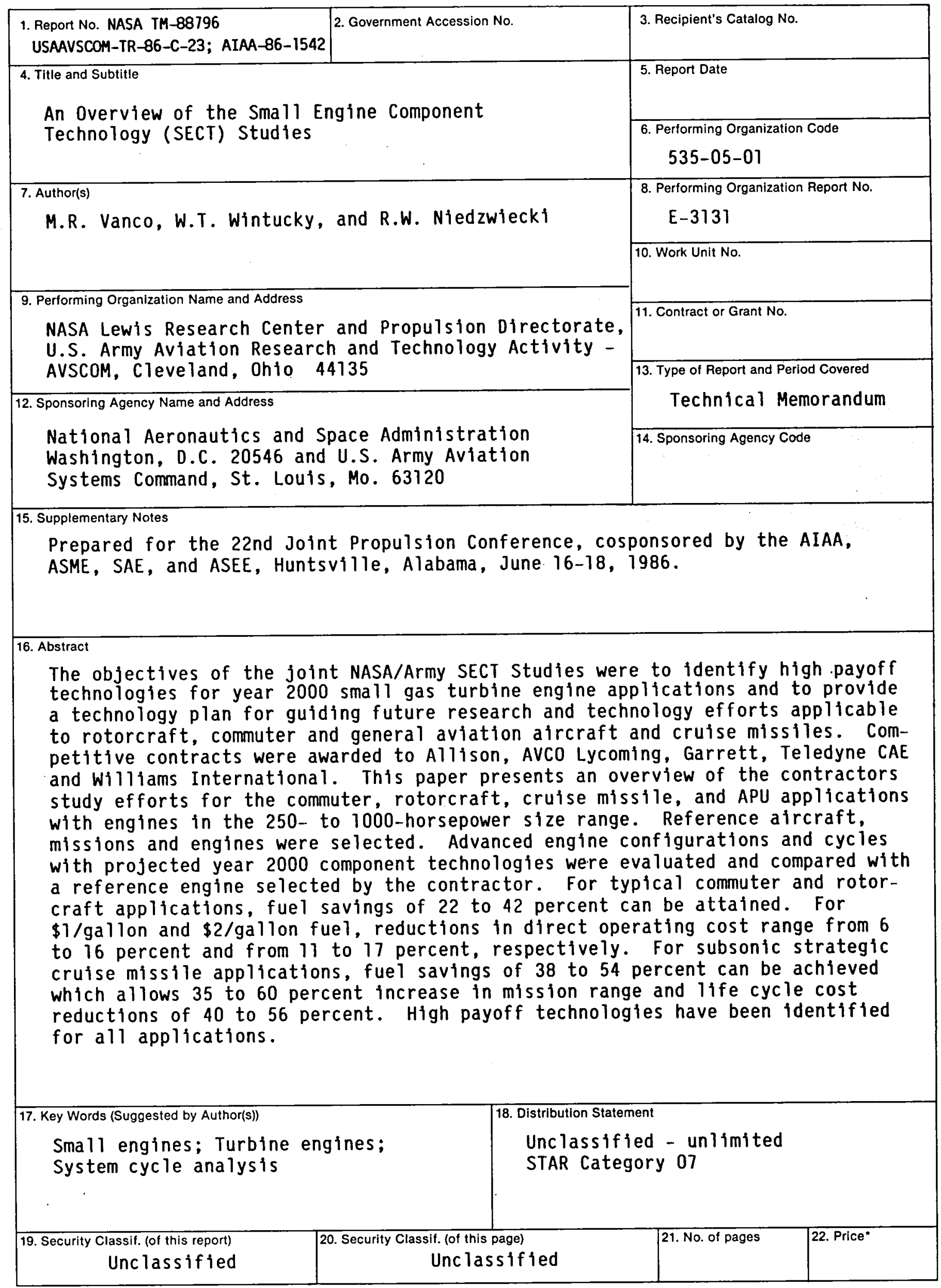

*For sale by the National Technical Information Service, Springfield, Virginia 22161 
National Aeronaulics and Space Administration

Lewis Research Center

Cleveland. Ohio 44135

Official Business

Penalty for Private Use $\$ 300$
ADDRESS CORRECTION REQUESTED

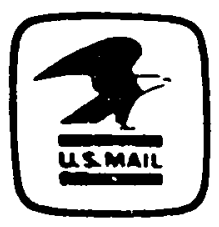

Postage and Fees Paid

National Aeronautics and

Space Administration

NASA-451 